\title{
Medicinal chemistry optimization of a diaminopurine chemotype: Towards a lead for Trypanosoma brucei inhibitors
}

Baljinder Singh, ${ }^{1 *}$ Rosario Diaz-Gonzalez, ${ }^{2}$ Gloria Ceballos-Perez, ${ }^{2}$ Domingo I. Rojas-Barros, ${ }^{2}$ Naresh Gunaganti, ${ }^{1}$ Kirsten Gillingwater, ${ }^{3,4}$ Maria Santos Martinez-Martinez, ${ }^{5}$ Pilar Manzano, ${ }^{6}$ Miguel Navarro, ${ }^{2}$ Michael P. Pollastri ${ }^{1 * *}$

${ }^{1}$ Department of Chemistry and Chemical Biology, Northeastern University, Boston, Massachusetts 02115, United States

${ }^{2}$ Instituto de Parasitología y Biomedicina "López-Neyra" Consejo Superior de Investigaciones Científicas (CSIC), Granada 18016, Spain

${ }^{3}$ Parasite Chemotherapy Unit, Swiss Tropical and Public Health Institute, Socinstrasse 57, 4051 Basel, Switzerland ${ }^{4}$ University of Basel, Petersplatz 1, 4001 Basel, Switzerland

${ }^{5}$ Tres Cantos Medicines Development Campus, DDW, GlaxoSmithKline, Tres Cantos 28760, Spain

*Corresponding author

b.singh@northeastern.edu (BS)

m.pollastri@northeastern.edu (MPP)

\section{Table of Contents}

\begin{tabular}{|l|l|}
\hline Data Tables, Figures and Bioassay results & S2 \\
\hline Biological Assays and ADME protocols & S6 \\
\hline LC Chromatograms & S8 \\
\hline References & S39 \\
\hline
\end{tabular}


Table S1. In vitro \% human plasma protein binding (PPB) and $\log \mathrm{D}_{7.4}$ data values for all synthesized compounds.

\begin{tabular}{|c|c|c|c|}
\hline Entry & Sample codes & Human PPB (\%) & $\log D_{7.4}$ \\
\hline 1 & NEU-0001106 & 95 & 3.1 \\
\hline 3 & NEU-0002588 & 94 & 2.1 \\
\hline $4 a$ & NEU-0002589 & 19 & 0.8 \\
\hline $4 b$ & NEU-0002590 & 19 & 1.4 \\
\hline $4 \mathrm{c}$ & NEU-0004807 & 96 & 3.3 \\
\hline 4d & NEU-0004808 & 98 & 3.8 \\
\hline $4 e$ & NEU-0004810 & 99 & 3.9 \\
\hline 4f & NEU-0004851 & 94 & 3.2 \\
\hline $4 \mathrm{~g}$ & NEU-0004456 & 97 & 3.6 \\
\hline $4 h$ & NEU-0004804 & 96 & 3.3 \\
\hline $4 i$ & NEU-0004809 & 99 & 4.2 \\
\hline $4 j$ & NEU-0004430 & 99 & 3.8 \\
\hline $4 k$ & NEU-0004852 & 96 & 3.6 \\
\hline 41 & NEU-0004941 & 100 & 4.8 \\
\hline $4 m$ & NEU-0004855 & 75 & 2.0 \\
\hline $4 n$ & NEU-0004881 & 97 & 3.7 \\
\hline 40 & NEU-0004883 & 98 & 3.8 \\
\hline $4 p$ & NEU-0004884 & 99 & $>4.5$ \\
\hline $4 q$ & NEU-0004885 & 98 & 3.8 \\
\hline $4 r$ & NEU-0004882 & 98 & 3.6 \\
\hline $4 s$ & NEU-0004805 & 27 & 0 \\
\hline $4 t$ & NEU-0004858 & 97 & 3.8 \\
\hline $4 u$ & NEU-0004850 & 81 & 2.1 \\
\hline $4 v$ & NEU-0004856 & 36 & 1.2 \\
\hline $4 w$ & NEU-0004857 & 54 & 1.7 \\
\hline $4 x$ & NEU-0004853 & 84 & 2.2 \\
\hline $4 y$ & NEU-0004878 & 93 & 2.7 \\
\hline $4 z$ & NEU-0004880 & 60 & 2.1 \\
\hline $4 \mathbf{a a}$ & NEU-0004854 & 72 & 1.9 \\
\hline $4 a b$ & NEU-0004879 & 48 & 1.4 \\
\hline $5 \mathbf{a}$ & NEU-0005046 & 94 & 2.2 \\
\hline $5 \mathbf{b}$ & NEU-0004968 & 94 & 2.9 \\
\hline $5 c$ & NEU-0005045 & 97 & 3.3 \\
\hline $5 d$ & NEU-0004949 & 99 & 3.9 \\
\hline $5 e$ & NEU-0005133 & 98 & 3.8 \\
\hline
\end{tabular}




\begin{tabular}{|c|c|c|c|}
\hline Entry & Sample codes & Human PPB (\%) & $\log D_{7.4}$ \\
\hline $5 f$ & NEU-0004907 & 89 & 2.5 \\
\hline $5 \mathrm{~g}$ & NEU-0004908 & 74 & 2.1 \\
\hline $5 \mathrm{~h}$ & NEU-0004911 & 99 & 3.5 \\
\hline $5 \mathbf{i}$ & NEU-0004912 & 98 & 3.2 \\
\hline $5 \mathbf{j}$ & NEU-0004942 & $78^{\mathrm{a}}$ & 1.6 \\
\hline $5 \mathbf{k}$ & NEU-0004943 & 98 & 3.6 \\
\hline 51 & NEU-0004944 & $99^{\mathrm{a}}$ & $>4.1$ \\
\hline $5 \mathrm{~m}$ & NEU-0004945 & $92^{\mathrm{a}}$ & 2.6 \\
\hline $5 n$ & NEU-0004946 & $98^{\mathrm{a}}$ & $>4.5$ \\
\hline 50 & NEU-0004947 & $96^{\mathrm{a}}$ & 3.2 \\
\hline $5 p$ & NEU-0004948 & $98^{\mathrm{a}}$ & 3.7 \\
\hline $5 \mathbf{q}$ & NEU-0004966 & 95 & 3.0 \\
\hline $5 r$ & NEU-0004967 & 98 & 4.0 \\
\hline $5 s$ & NEU-0004994 & 100 & 3.8 \\
\hline $5 t$ & NEU-0005012 & 99 & 3.8 \\
\hline $5 \mathbf{u}$ & NEU-0005134 & 48 & 1.0 \\
\hline $5 v$ & NEU-0004905 & 90 & 2.6 \\
\hline $5 w$ & NEU-0004906 & 74 & 2.3 \\
\hline $5 x$ & NEU-0004909 & 99 & 3.9 \\
\hline $5 y$ & NEU-0004910 & 97 & 3.3 \\
\hline $5 z$ & NEU-0004939 & $81^{\mathrm{a}}$ & 1.7 \\
\hline $5 \mathbf{a a}$ & NEU-0004400 & $84^{\mathrm{a}}$ & 1.9 \\
\hline $5 \mathbf{a b}$ & NEU-0005407 & 51 & 1.1 \\
\hline 5 ac & NEU-0005308 & 84 & 2.5 \\
\hline 5 ad & NEU-0005307 & 28 & -0.20 \\
\hline 5 ae & NEU-0005011 & 88 & 2.5 \\
\hline $9 a$ & NEU-0005515 & 98 & 3.3 \\
\hline $9 b$ & NEU-0005516 & 71 & 1.9 \\
\hline 10 & NEU-0005831 & 99 & 4 \\
\hline 11 & NEU-0005832 & 100 & 4.1 \\
\hline $13 \mathbf{a}$ & NEU-0004886 & 93 & 3.1 \\
\hline $13 b$ & NEU-0004887 & 95 & 3.3 \\
\hline
\end{tabular}


Table S2. Individual blood pharmacokinetic parameters of 4aa (NEU-4854), after intraperitoneal administration of $10 \mathrm{mg} / \mathrm{kg}$ single dose (target dose) to female NMRI mice $(\mathrm{n}=3)$.

\begin{tabular}{|c|c|c|c|c|c|}
\hline Mouse ID & $\mathbf{C}_{\max }(\mathbf{n g} / \mathbf{m L})$ & $\mathbf{t}_{\max }(\mathbf{h})$ & $\mathbf{A U} \mathbf{C}_{\mathbf{0}-\mathbf{t}}(\mathbf{n g} \cdot \mathbf{h} / \mathbf{m l})$ & $\mathbf{A U C}(\mathbf{n g} \cdot \mathbf{h} / \mathbf{m l})$ & $\mathbf{t}_{\mathbf{1} / \mathbf{2}}(\mathbf{h})$ \\
\hline $\mathbf{0 1 9 F}$ & 4730 & 0.25 & 8610 & $8630^{\mathrm{a}}$ & $0.796^{\mathrm{a}}$ \\
\hline $\mathbf{0 2 0 F}$ & 3100 & 0.5 & 4080 & 4090 & 0.451 \\
\hline $\mathbf{0 2 1 F}$ & 3170 & 0.25 & 3320 & 5330 & 0.758 \\
\hline Mean & 3670 & \multirow{2}{*}{$0.25-0.5$} & 5340 & 2870 & 0.290 \\
\hline SD & 922 & & 2860 & & 5350 \\
\hline
\end{tabular}

${ }^{a} \mathrm{r}<0.95$

Table S3. Blood and brain levels of 4aa (NEU-4854), after intraperitoneal administration of 10 $\mathrm{mg} / \mathrm{kg}$ single dose (target dose) to female NMRI mice $(\mathrm{n}=3)$.

\begin{tabular}{|c|c|c|c|c|c|c|}
\hline Time (h) & Matrix & N1 & $\mathbf{N 2}$ & N3 & Mean & SD \\
\hline \multirow{3}{*}{0.5} & Blood & 3460 & 3130 & 2680 & 3090 & 392 \\
\hline & Brain & 486 & 128 & 77.9 & 231 & 223 \\
\hline & Brain/Blood Ratio & 0.140 & 0.04 & 0.03 & 0.07 & 0.061 \\
\hline \multirow{3}{*}{4} & Blood & 13.2 & 20.5 & 19.7 & 18 & 4 \\
\hline & Brain & $<10-0$ & $<10.0$ & 15.0 & 11.7 & 2.9 \\
\hline & Brain/Blood Ratio & $<0.758$ & $<0.49$ & 0.76 & $<0.67$ & $\mathrm{NC}^{\mathrm{a}}$ \\
\hline
\end{tabular}

${ }^{\mathrm{a}} \mathrm{NC}=$ not calculated

Table S4. Blood pharmacokinetic parameters of 4aa at intraperitoneal administration of $30 \mathrm{mg} / \mathrm{kg}$ (target dose) after ABT-pretreatment to female NMRI mice (infected and non-infected) on day 1 and day 5 of treatment.

\begin{tabular}{|c|c|c|c|c|c|}
\hline Mouse ID & $\begin{array}{c}\text { Mean } C_{\max } \\
(\mathrm{ng} / \mathrm{mL}) \pm \mathrm{SD}\end{array}$ & Mean $t_{\max }(h)$ & Mean $t_{1 / 2}(h)$ & $\begin{array}{c}\text { Mean AUC }{ }_{0-t} \\
(n g \cdot h / m l)\end{array}$ & $\begin{array}{c}\text { Mean AUC } \\
(\mathbf{n g} \cdot \mathbf{h} / \mathbf{m l})\end{array}$ \\
\hline $\begin{array}{l}\text { Infected mouse, day } \\
1 \text { of treatment }\end{array}$ & $17267 \pm 1258$ & $0.5-2.0$ & $1.58 \pm 1.11$ & $77666 \pm 15686$ & $83443 \pm 26918$ \\
\hline $\begin{array}{l}\text { Non-infected mouse, } \\
\text { day } 1 \text { of treatment }\end{array}$ & $15767 \pm 3007$ & $0.5-2.0$ & $0.638 \pm 0.047$ & $51799 \pm 15424$ & $52521 \pm 16034$ \\
\hline $\begin{array}{c}\text { Infected mouse, day } \\
5 \text { of treatment }\end{array}$ & $14250 \pm 212$ & 0.5 & $0.626 \pm 0.032$ & $34414 \pm 5673$ & $34548 \pm 5733$ \\
\hline $\begin{array}{l}\text { Non-infected mouse, } \\
\text { day } 5 \text { of treatment }\end{array}$ & $18500 \pm 1838$ & 0.5 & $0.619 \pm 0.176$ & $44868 \pm 4123$ & $45071 \pm 4034$ \\
\hline
\end{tabular}




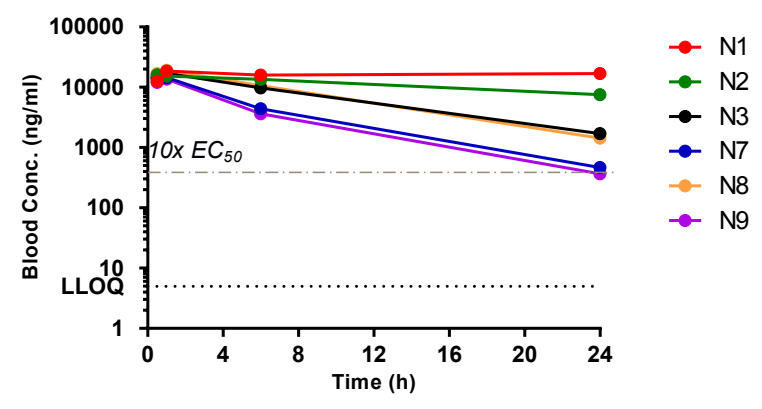

A



B

Figure S1. (A) in vivo pharmacokinetics data of 4aa at dose $30 \mathrm{mg} / \mathrm{kg}$ ip after ABT-pretreatment in Tbb STIB795 infected mice (N1-N3) and uninfected mice (N7-N9) on day 1 of treatment; (B) in vivo pharmacokinetics data of 4aa at dose $30 \mathrm{mg} / \mathrm{kg}$ ip after ABT-pretreatment in Tbb STIB795 infected mice (N2-N3) and uninfected mice (N7-N9) on day 5 of treatment.



Figure S2. Percent inhibition of a human kinase panel for $\mathbf{4 a a}$ tested at a $5 \mu \mathrm{M}$ concentration

\section{Results of T. brucei mitogen-activated protein kinase (TbMAPK6) inhibition.}

Mitogen-activated protein kinases (MAPKs) play an important role in the cell cycle and can be utilized as a target for developing $T$. brucei inhibitors. ${ }^{1,2}$ There are several MAPKs known in $T$. brucei and TbMAPK6 (K5140) is one of the potential MAPKs which controls cytokinesis in two life cycle forms of $T$. brucei. ${ }^{3,4} \mathrm{~K} 5140$ is homologous to the human extracellular-signal regulated 
kinase 8 (HsERK8) ; and there are purine based compounds like bohemine, roscovitine and CR8 reported in literature inhibiting human ERK8. ${ }^{6-8}$ Given the inhibitory potential of 4aa (NEU-4854) against proliferation of T. brucei followed by the potential in animal efficacy models in increasing the life span of infected animals, we decided to evaluate the effect of 4aa (NEU-4854) along with parent compound 1 (NEU-1106) against one of the kinase targets of trypanosomes, i.e. TbMAPK6. Compound 4aa (NEU-4854) was found to be a better inhibitor of TbMAPK6 over 1 (NEU-1106) with $\mathrm{IC}_{50}$ values of 1.2 and $7.6 \mu \mathrm{M}$ respectively.

Protocol for enzyme activity (TbMAPK6) measurement. The trypanosomal kinase encoded by gene Tb927.10.5140 (K5140) (Gene DB nomenclature, also known as Tb10.70.2070 and Q38B88 in UniProtKB) (= TbMAPK6) is a MAP kinase which is a homolog of human MAPK15, or ERK7/8. The full length T. brucei K5140 kinase was subcloned into E. coli vectors containing an $\mathrm{N}$-terminal $8 \mathrm{His}$ fusion and purified through a Ni-IMAC column. To measure the activity of compounds against the enzyme the compounds were diluted to 30 or $3 \mu \mathrm{M}$ in $10 \%$ DMSO (v/v) in assay buffer (15 mM HEPES, $20 \mathrm{mM} \mathrm{NaCl}, 10 \mathrm{mM} \mathrm{MgCl} 2,1 \mathrm{mM}$ EGTA, $0.02 \%$ (v/v) Tween 20, adjusted to $\mathrm{pH}$ 7.4). Assays were run in duplicate at $10 \mu \mathrm{M}$ ATP, $10 \mu \mathrm{M}$ myelin basic protein (MBP) and $25 \mathrm{nM} \mathrm{K5} 140$ to a final volume of $15 \mu \mathrm{M}$ and final DMSO concentration of $1 \%$ in 384-well OptiPlates (Perkin Elmer) at $37^{\circ} \mathrm{C}$ for $30 \mathrm{~min}$. Staurosporine, a general protein kinase inhibitor, was used as a positive control. Reactions were stopped and subsequently measured with ADP-Glo detection system (Promega) per the manufacturer's instructions on a Luminoskan Ascent luminometer (Thermo Labsystems). ATP in the absence of K5140 was used as background, and background-subtracted measurements were compared to control containing 1 $\%$ DMSO and no compound. Dose responses were analyzed using a non-linear regression fit in GraphPad Prism 6.

Aqueous pH 7.4 Solubility. Compounds are dried down from $10 \mathrm{mM}$ DMSO solutions using centrifugal evaporation technique. Phosphate buffer (0.1 M, pH 7.4) was added and StirStix inserted in the glass vials, and shaking is then performed at a constant temperature of $25^{\circ} \mathrm{C}$ for 20-24 h. This step is followed by double centrifugation with a tip wash in between, to ensure that no residues of the dried compound are interfering. The solutions are diluted before analysis and quantification using LC/MS/ MS is performed. 
$\log \mathbf{D}_{7.4}$. The distribution coefficient between 1-octanol and aqueous buffer, $\log \mathrm{D}$, at $\mathrm{pH}$ 7.4 , is based on the traditional shake flask technique but with the modification of measuring compounds in mixtures of 10 at a time using UPLC with quantitative MS to measure the relative octanol and aqueous concentrations of compounds. The buffer solution used is $10 \mathrm{mM}$ sodium phosphate ( $\mathrm{pH}$ 7.4). The method has been validated for log $\mathrm{D} 7.4$ ranging from -2 to 5.0.

Human Plasma Protein Binding (PPB). PPB is determined using equilibrium dialysis (RED device) to separate free from bound compound. The amount of compound in plasma ( $1 \mathrm{mM}$ initial concentration in DMSO) and in dialysis buffer ( $\mathrm{pH} 7.4$ phosphate buffer) is measured by LC/MS/MS after $18 \mathrm{~h}$ in a dialysis chamber at $37^{\circ} \mathrm{C}$. Sample levels are quantified using a sevenpoint calibration curve in plasma. The fraction unbound (fu, \%) is reported.

Human Liver Microsomal Clint. In vitro intrinsic clearance was determined from human liver microsomes using a standard approach. ${ }^{9}$ Following incubation and preparation, the samples are analyzed using LC/MS/MS. Refined data are uploaded to IBIS and are displayed as Clint (intrinsic clearance) in $(\mu \mathrm{L} / \mathrm{min}) / \mathrm{mg}$ protein.

Rat Hepatocyte Clint. In vitro intrinsic clearance was determined from rat han Wistar hepatocytes at a final concentration of 1 million cells $/ \mathrm{mL}$. The cells were preincubated at $37{ }^{\circ} \mathrm{C}$ for $15 \mathrm{~min}$ before addition of test compound (as a $50 \mu \mathrm{M}$ stock solution) to a final concentration of $1 \mu \mathrm{M}$. The samples were analyzed using LC/MS/MS at predefined time points. Refined data were uploaded to IBIS and are displayed as Clint (intrinsic clearance) $(\mu \mathrm{L} / \mathrm{min}) / 1$ million cells.

Calculated $\log \mathbf{P}$ and $\log \mathbf{D}$ Values. Both $\log \mathrm{P}$ and $\log \mathrm{D}$ predictions are based on a modified version of the method ${ }^{10}$ where the predicted partition coefficients are composed of the molecules' atomic increments.

Matrix Stability. For stability in mouse matrix, CD-1 is determined at $37^{\circ} \mathrm{C}$. The assay is performed by adding $500 \mu \mathrm{M}$ compound solution to the matrix to achieve a final concentration of $2 \mu \mathrm{M}$. Following incubation for $60 \mathrm{~min}$, the samples are quenched and analyzed using LC/MS to determine the percentage of drug remaining.

Caco-2 Permeability. The Caco-2 permeability of test compounds is measured using an established protocol at Charles River Labs. Concentration of test compounds is determined by 
measuring the peak area rations at $\mathrm{T}=0$ and $2 \mathrm{~h}$ on the apical and basolateral sides of the basal plate.

CYP Induction. CYP induction is measured using established protocols at Charles River Labs. The assay is performed by adding the test compound to the positive or negative controls, incubating for $3 \mathrm{~h}$ at $37{ }^{\circ} \mathrm{C}$, following determination of the fold-induction relative to the vehicle control by LC/MS/MS analysis.

CYP Inhibition. CYP inhibition is measured using established protocols at Charles River Labs. A $50 \mathrm{mM}$ stock solution was prepared and serially diluted (1.5-fold and 4-fold). This was then combined with a buffer/cofactor/substrate solution before combining with the human liver microsomes. The resulting mixture was incubated at $37^{\circ} \mathrm{C}$ for $30 \mathrm{~min}$ with gentle shaking before the percentage inhibition was calculated relative to zero inhibition by LC/ MS/MS analysis.

Trypanosoma congolense and $T$. vivax in vitro assays. The protocols for the biological assays of $T$. congolense and T. vivax were performed as previously described. ${ }^{11}$

\section{LC CHROMATOGRAMS OF ALL COMPOUNDS}

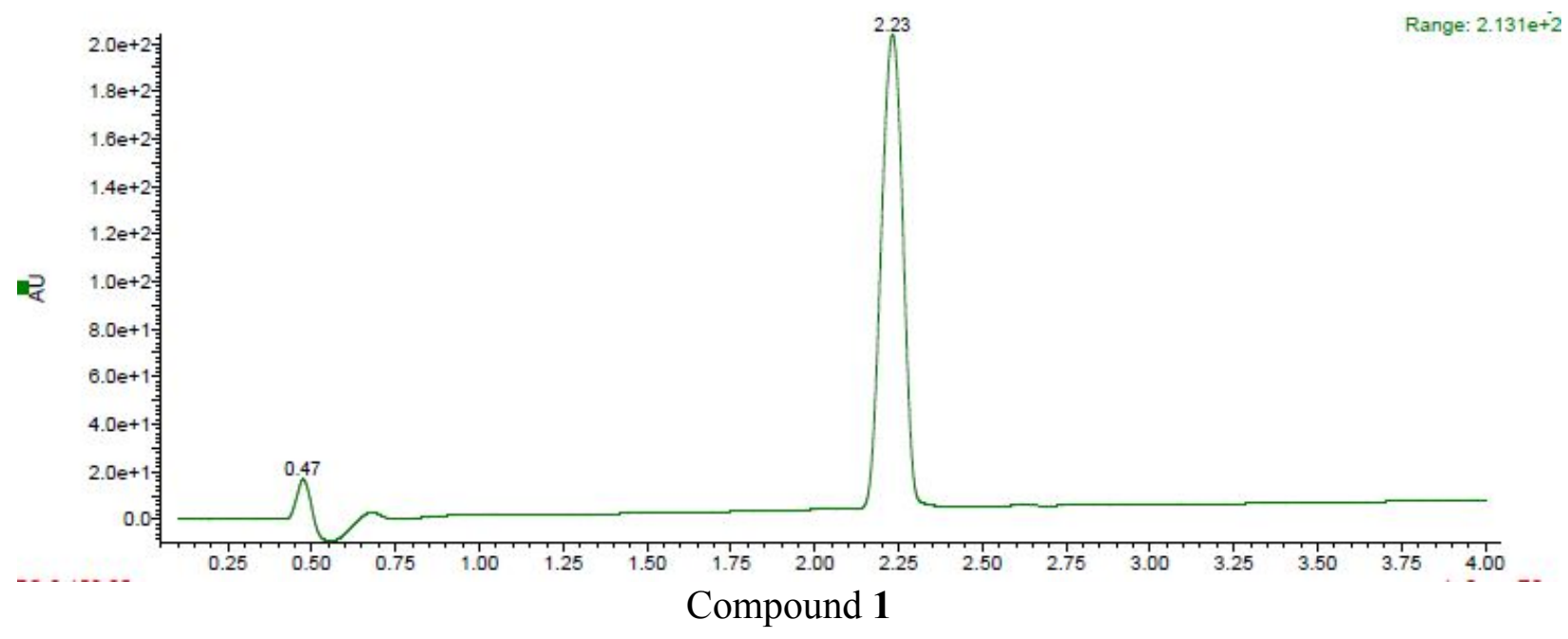






Compound $\mathbf{3}$
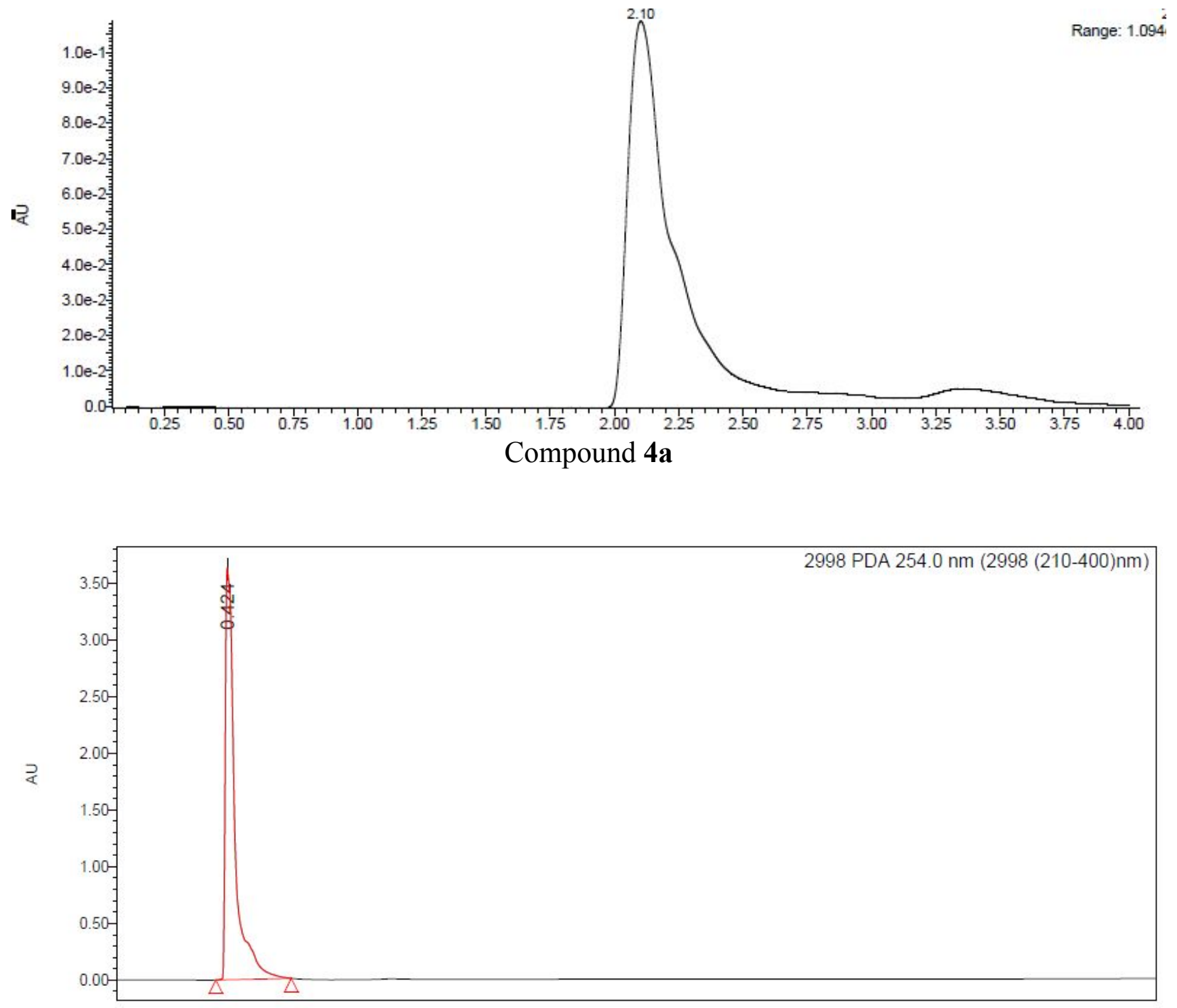


\section{Compound 4b}
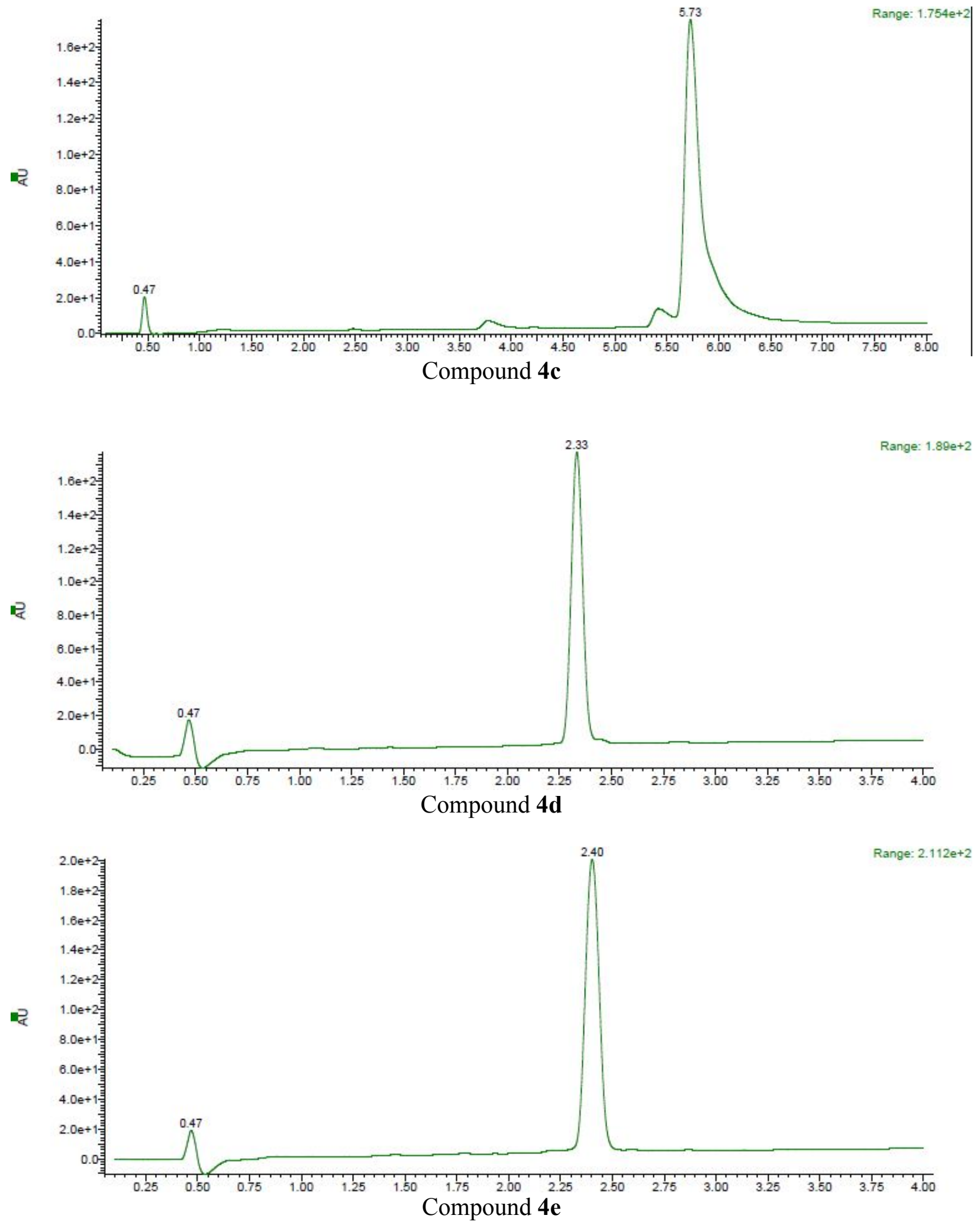

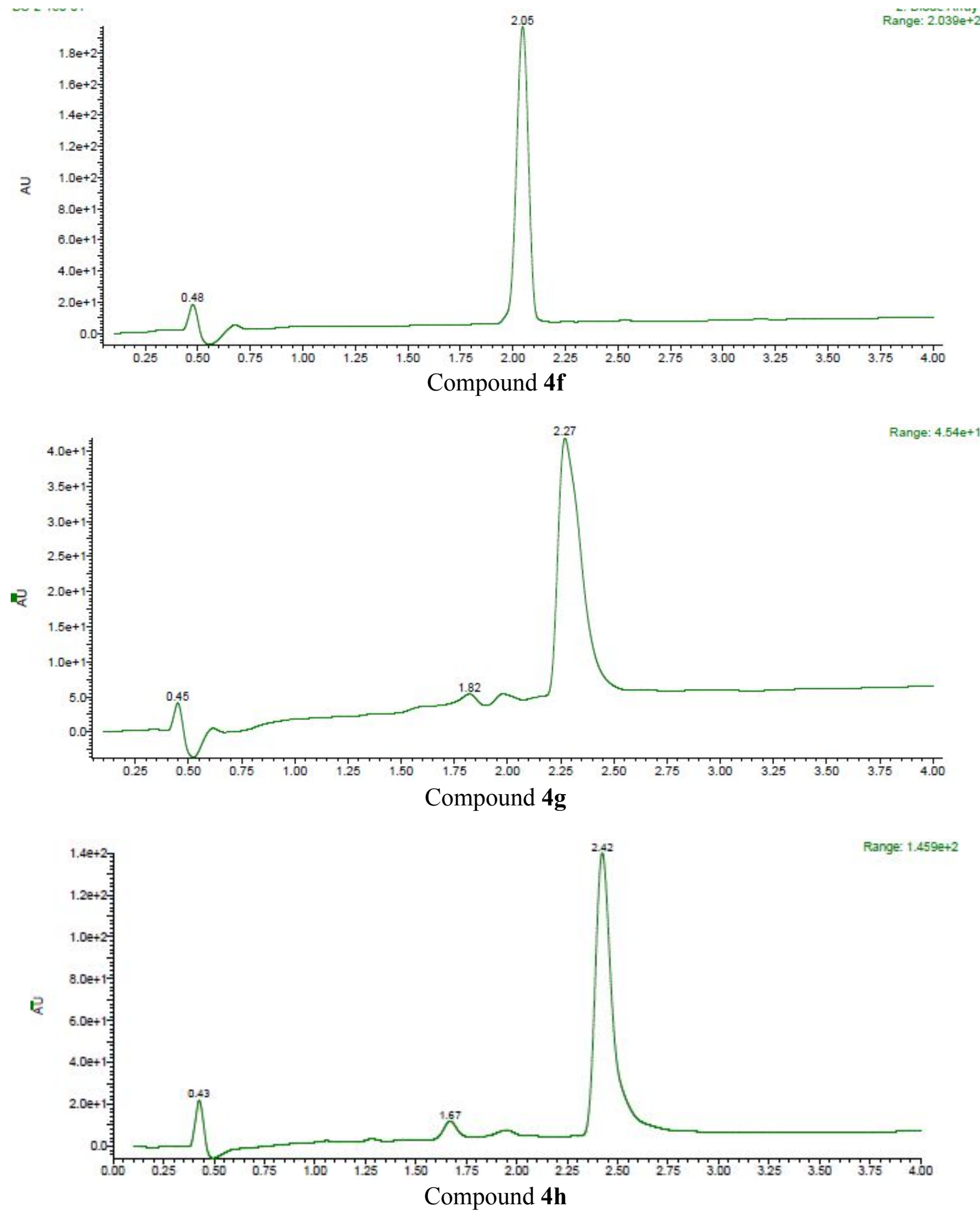



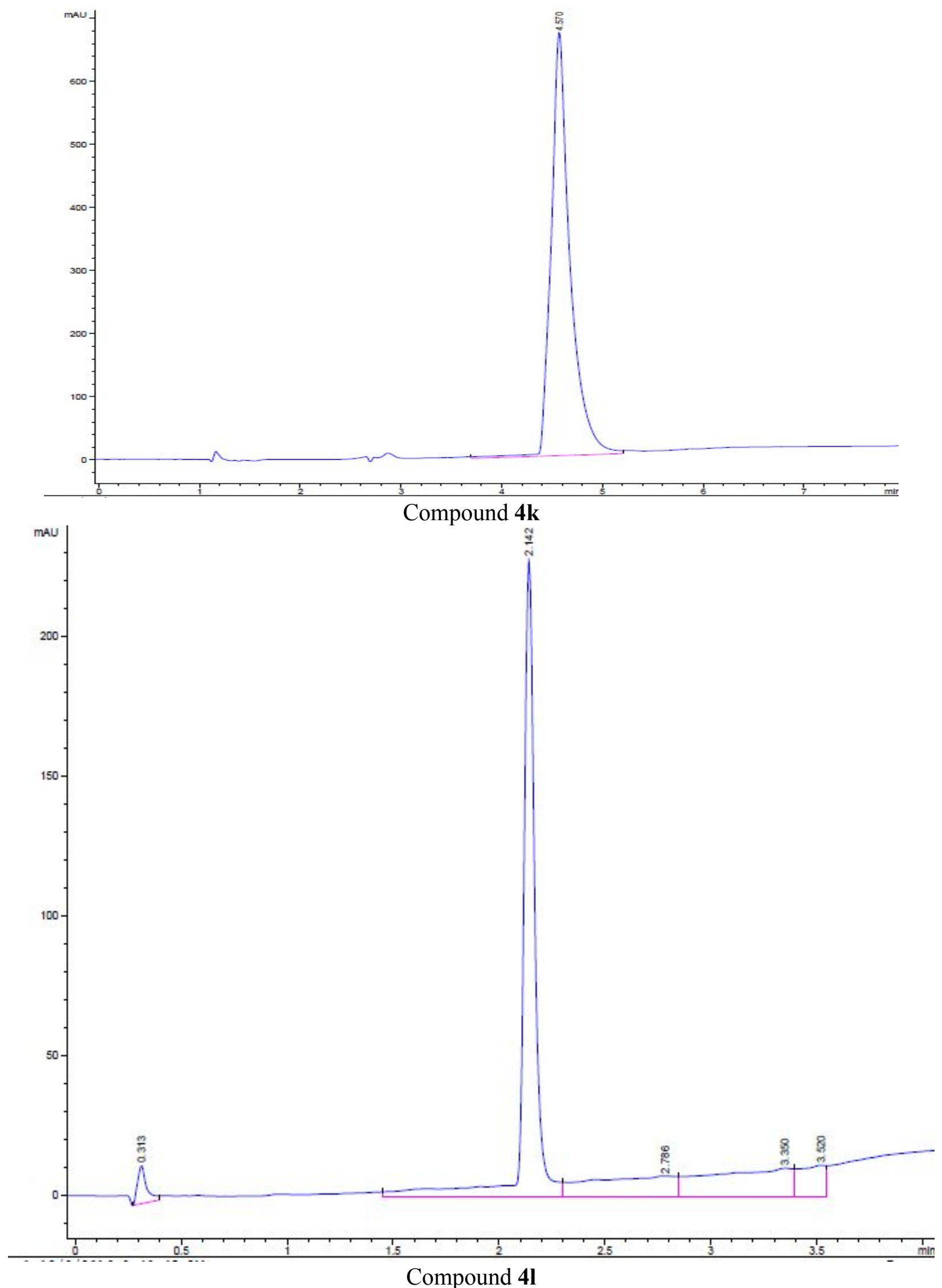

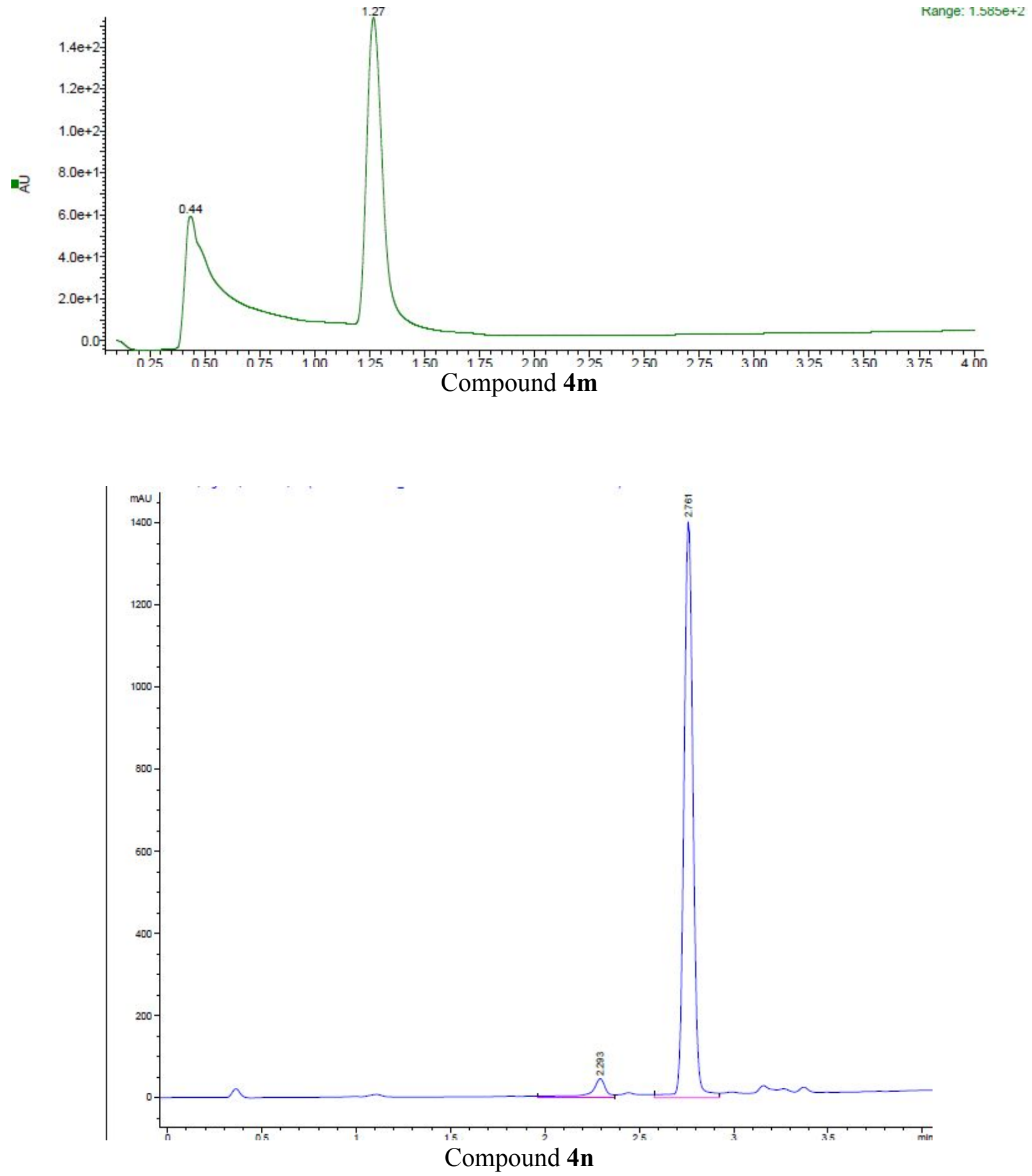

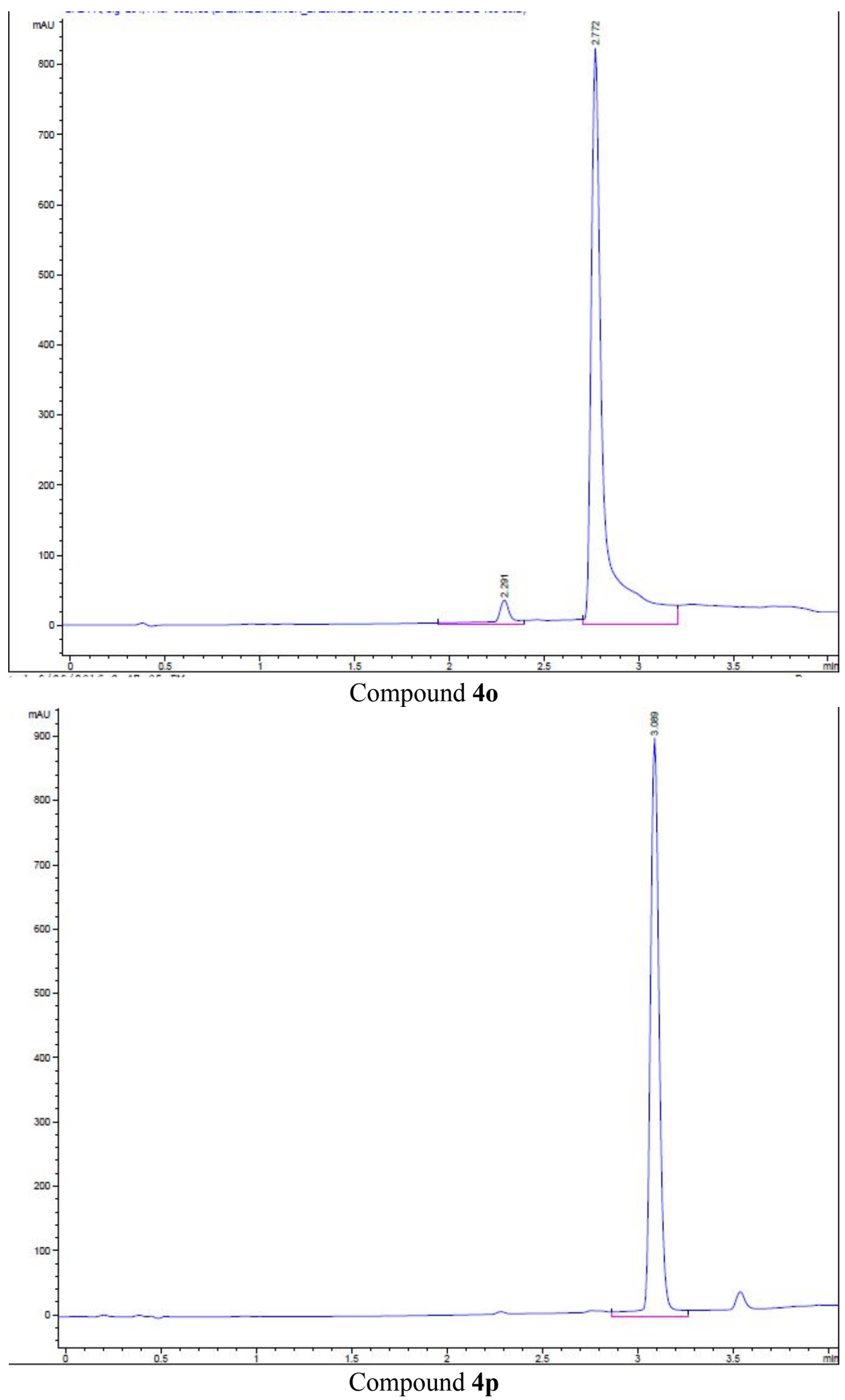


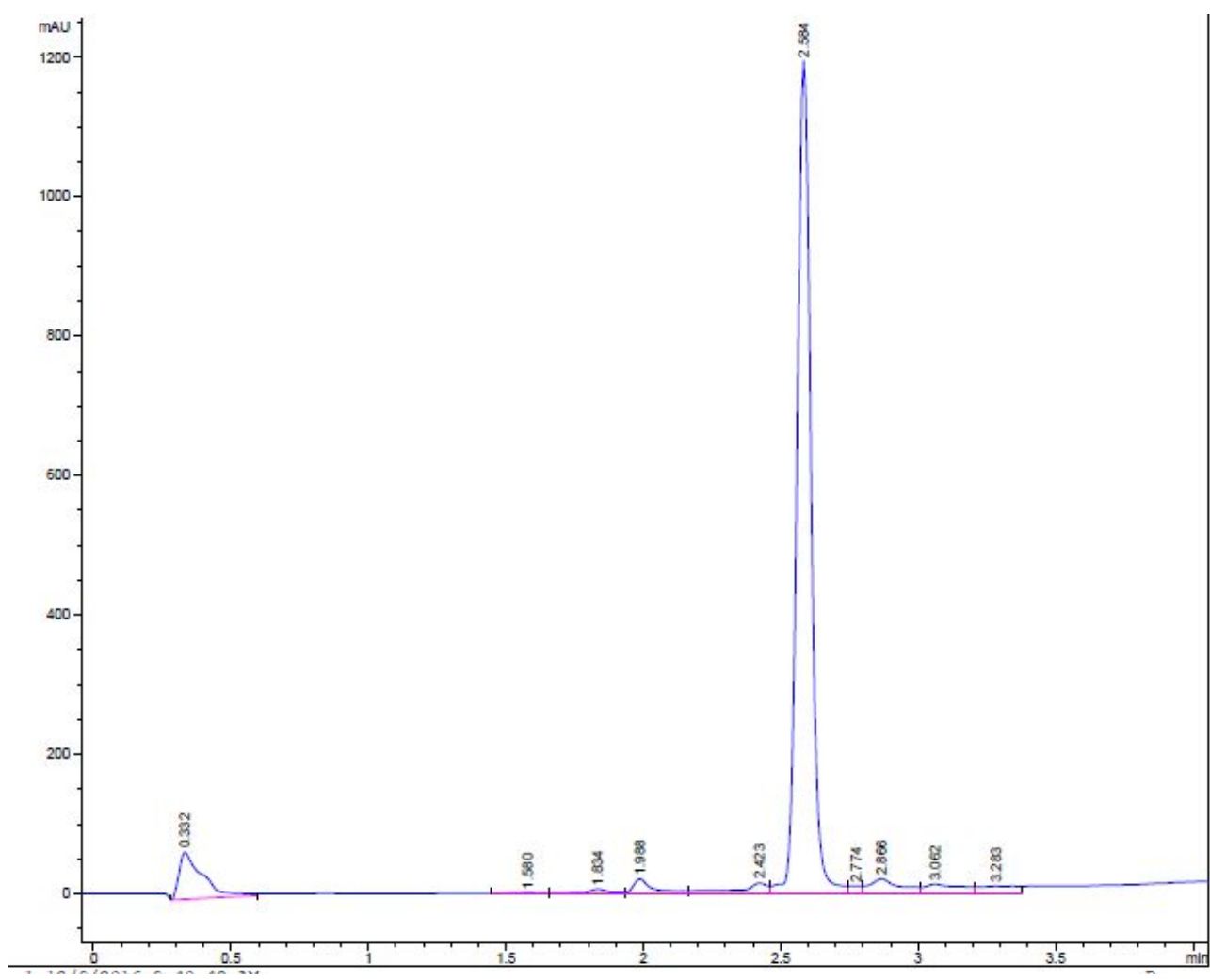

Compound 4q 



Compound $4 \mathbf{s}$ 

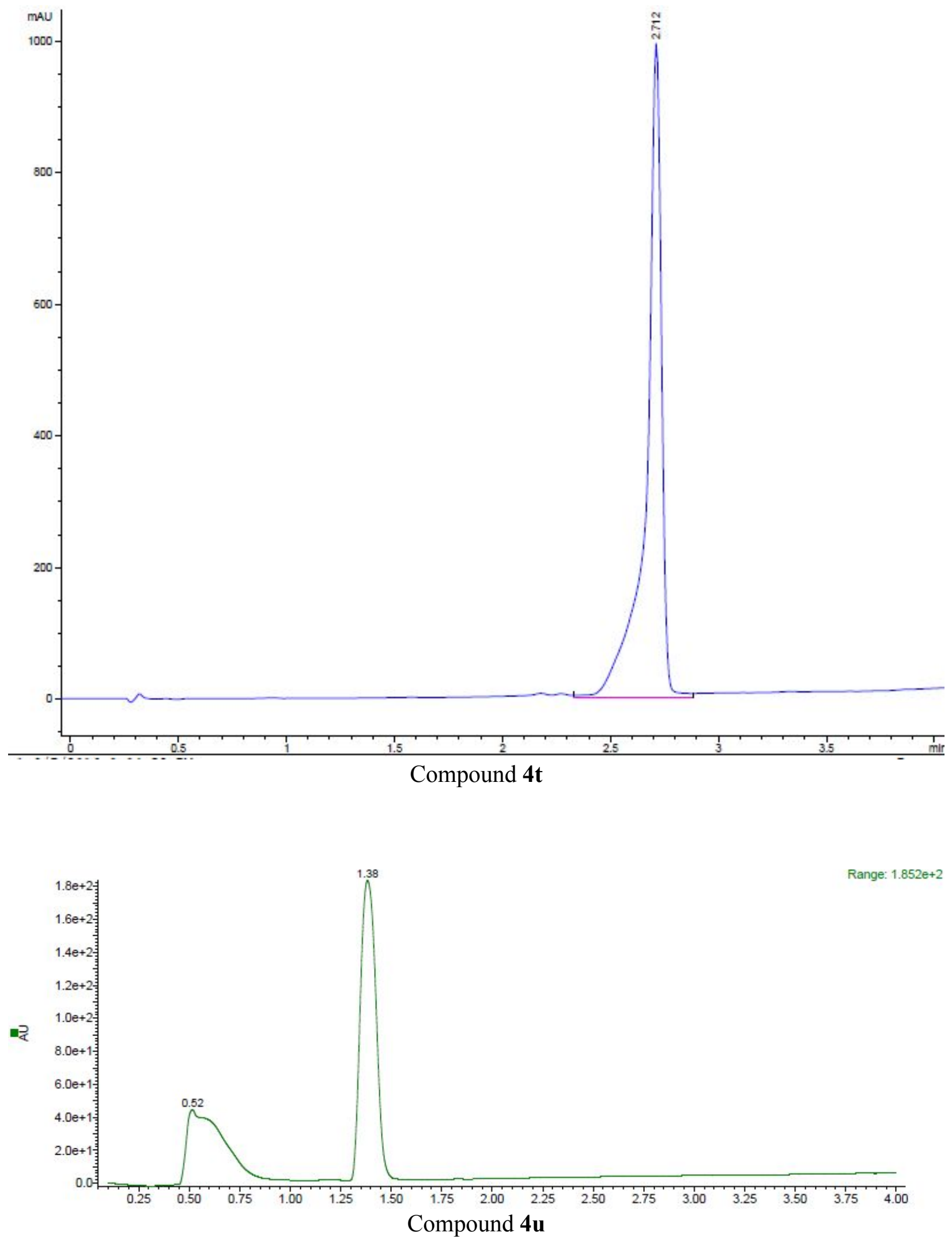


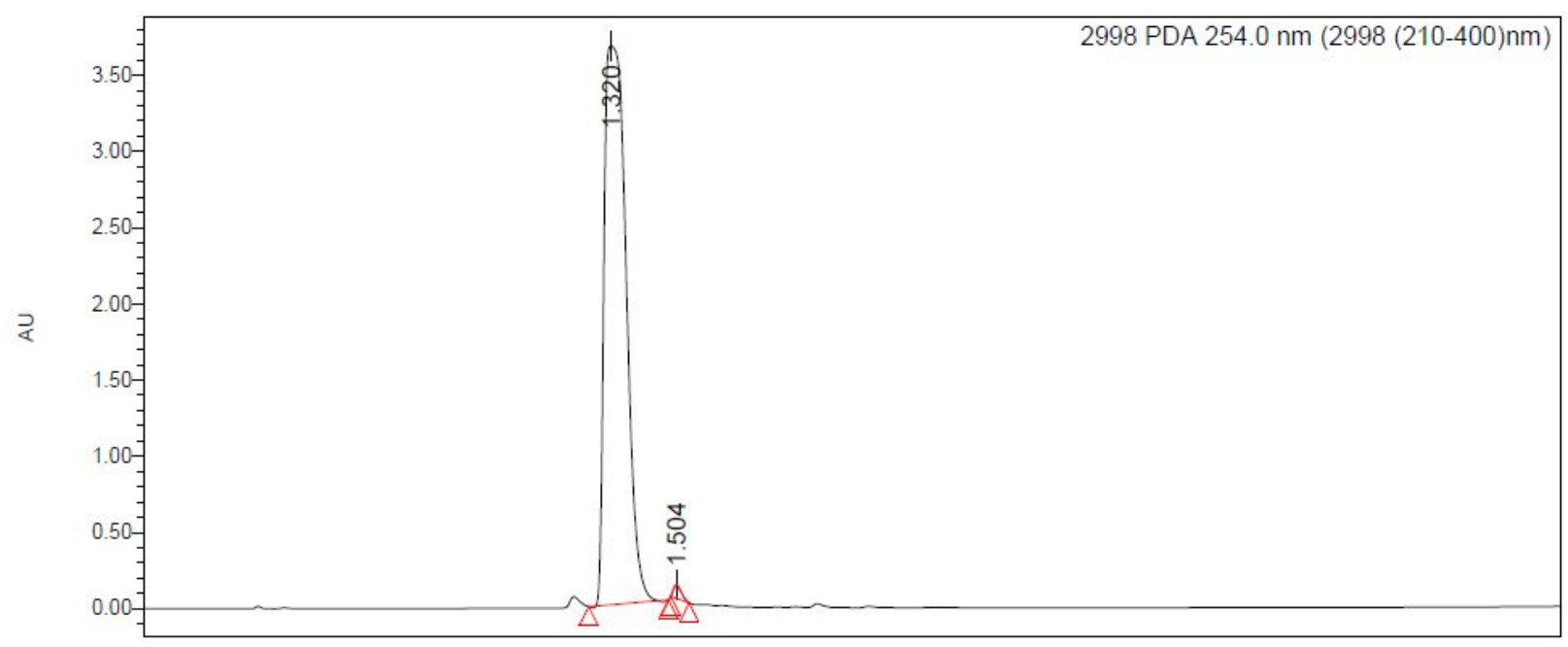

Compound 4v

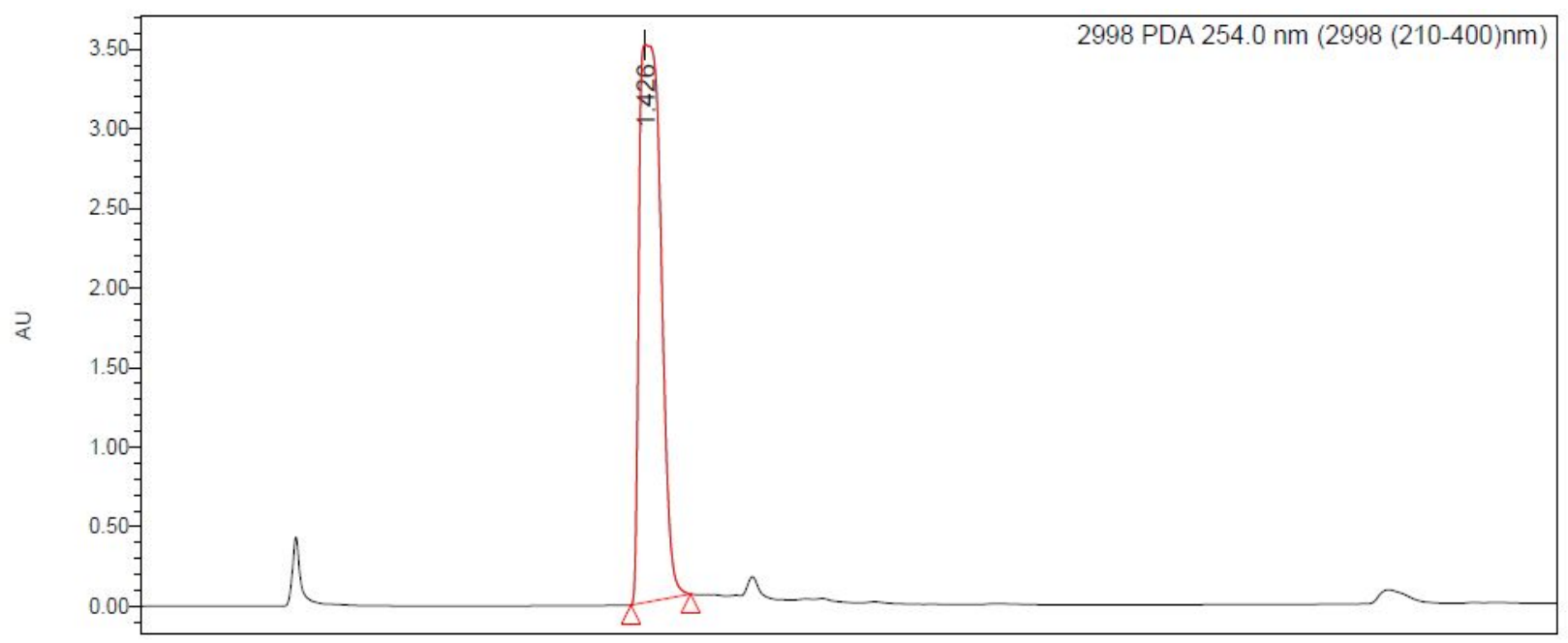

\section{Compound $\mathbf{4 w}$}



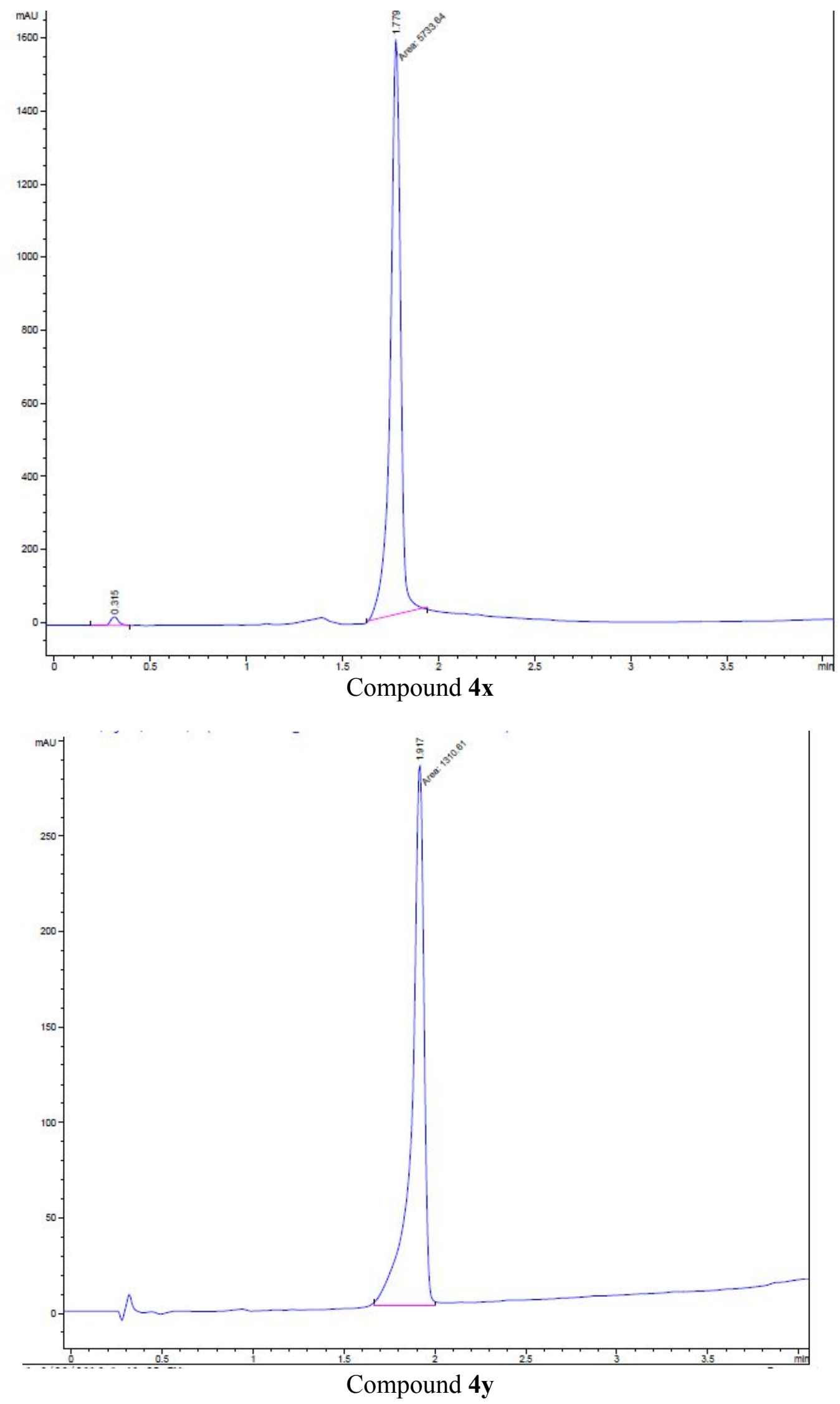

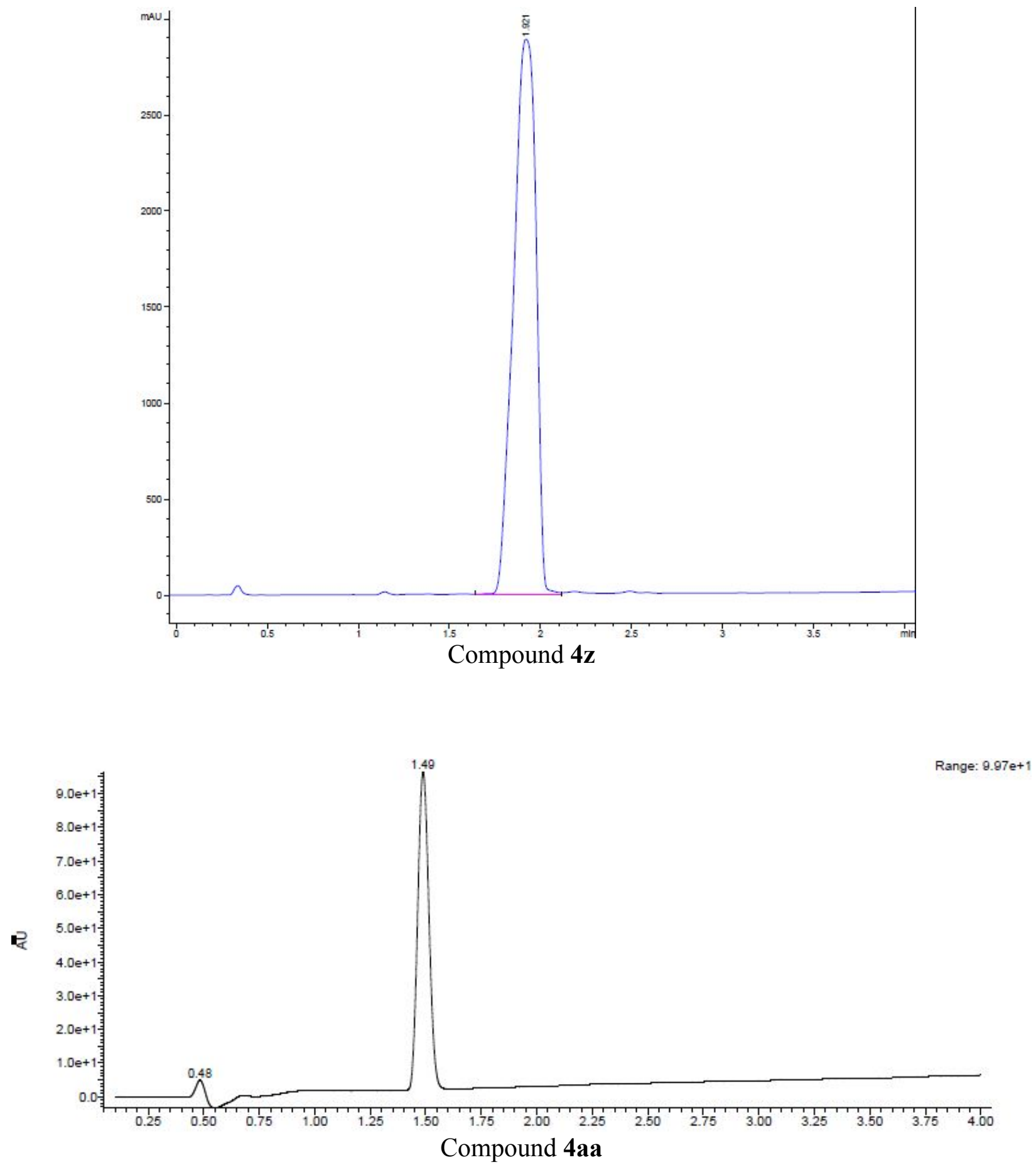

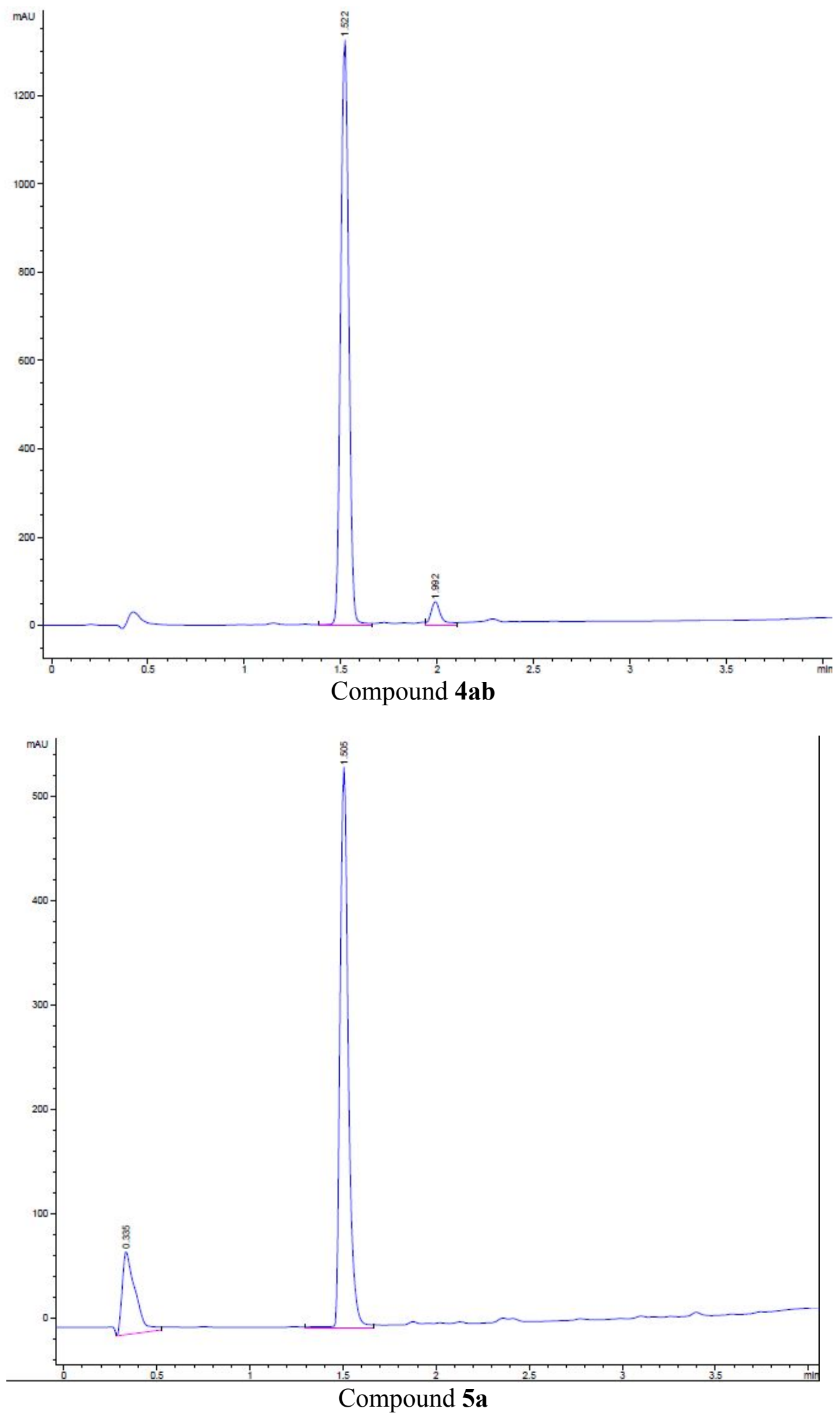

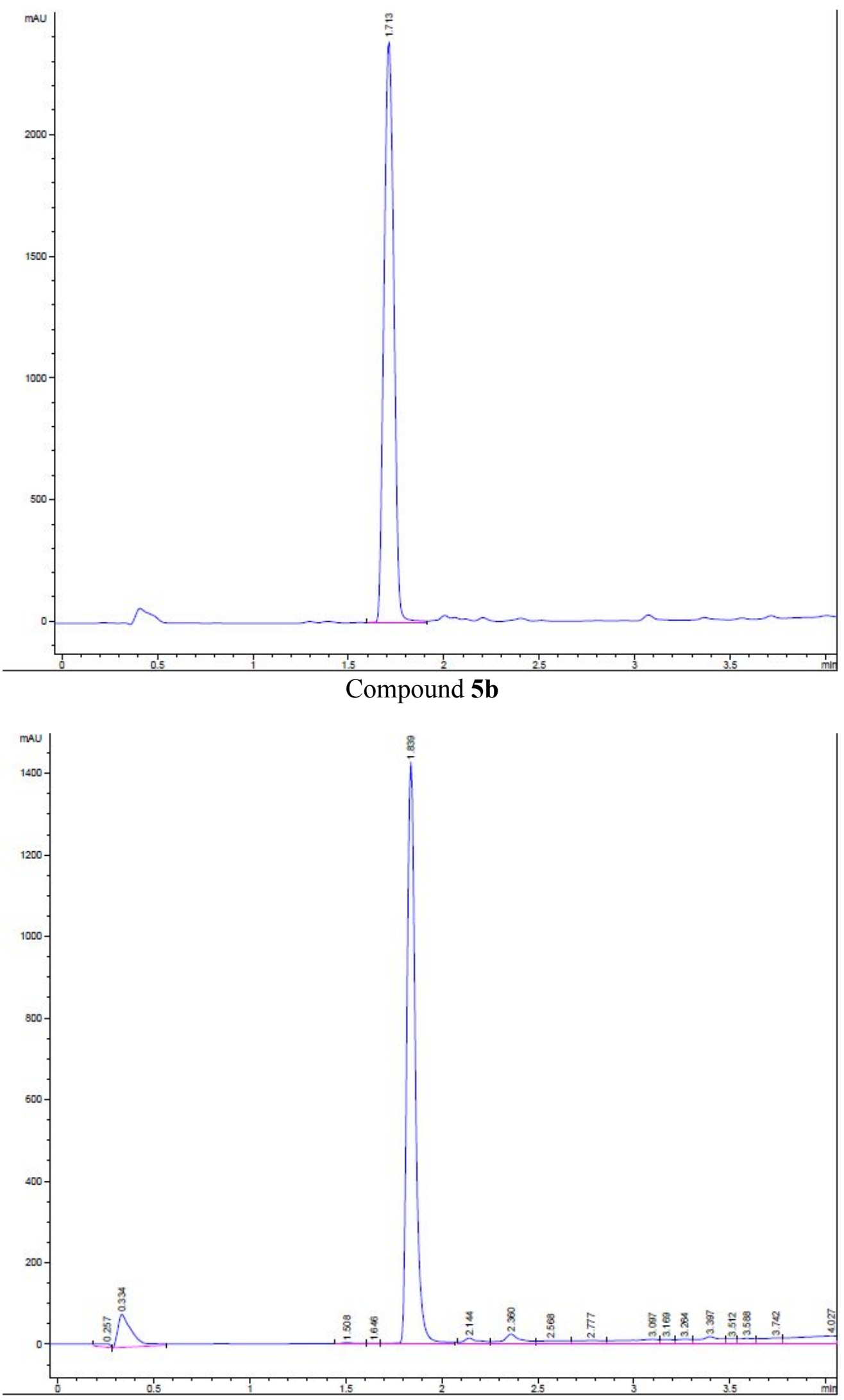


\section{Compound 5c}
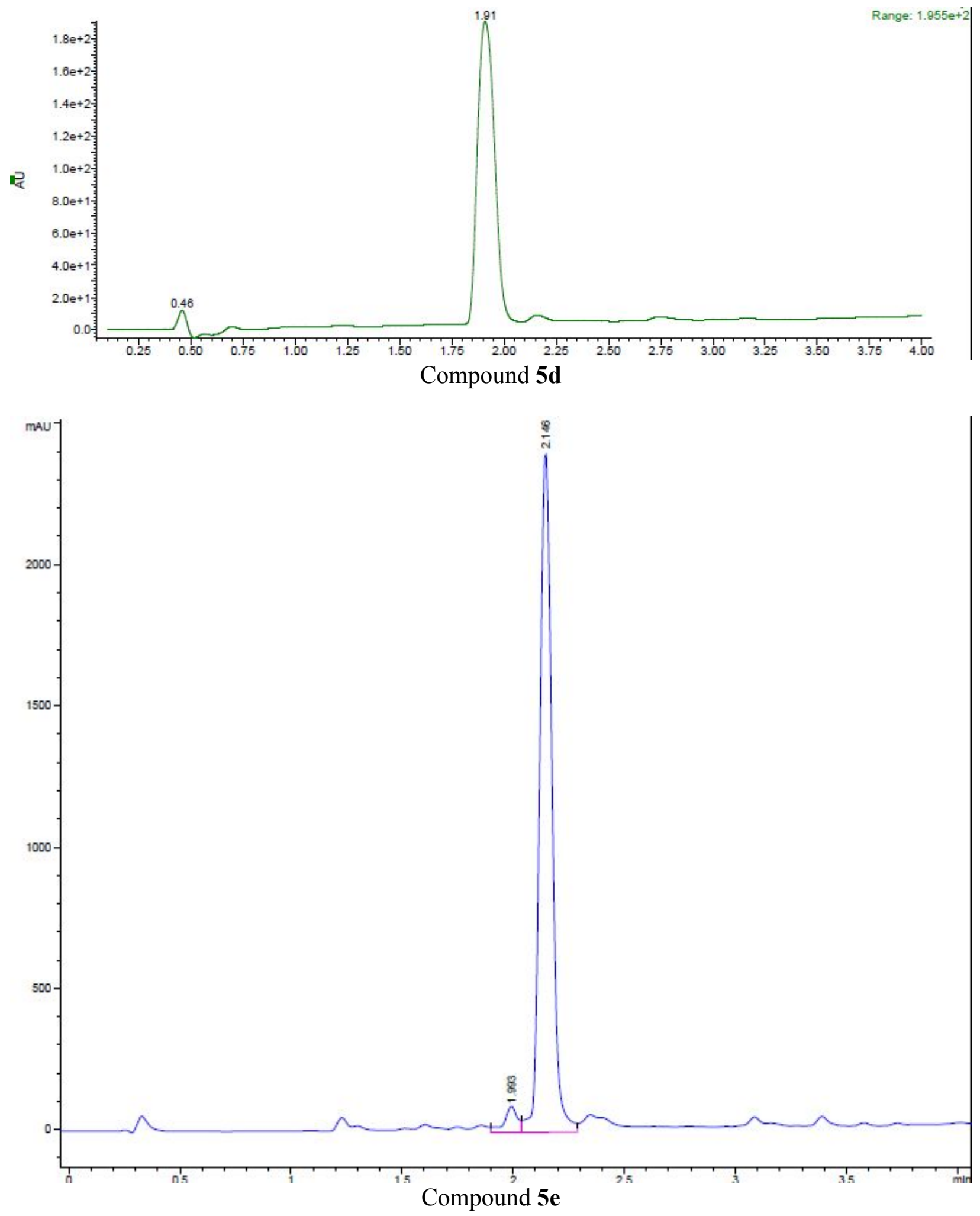







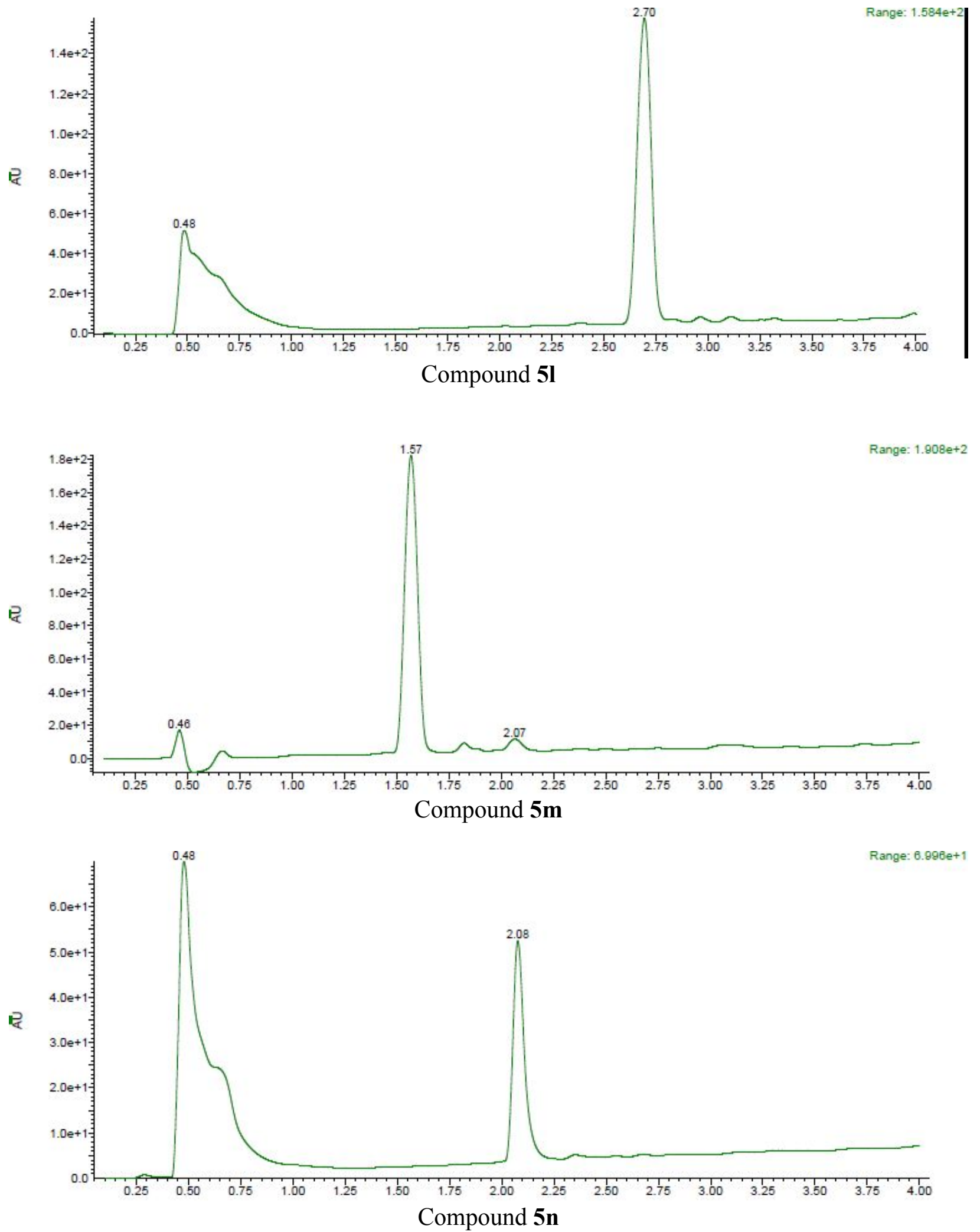

S28 

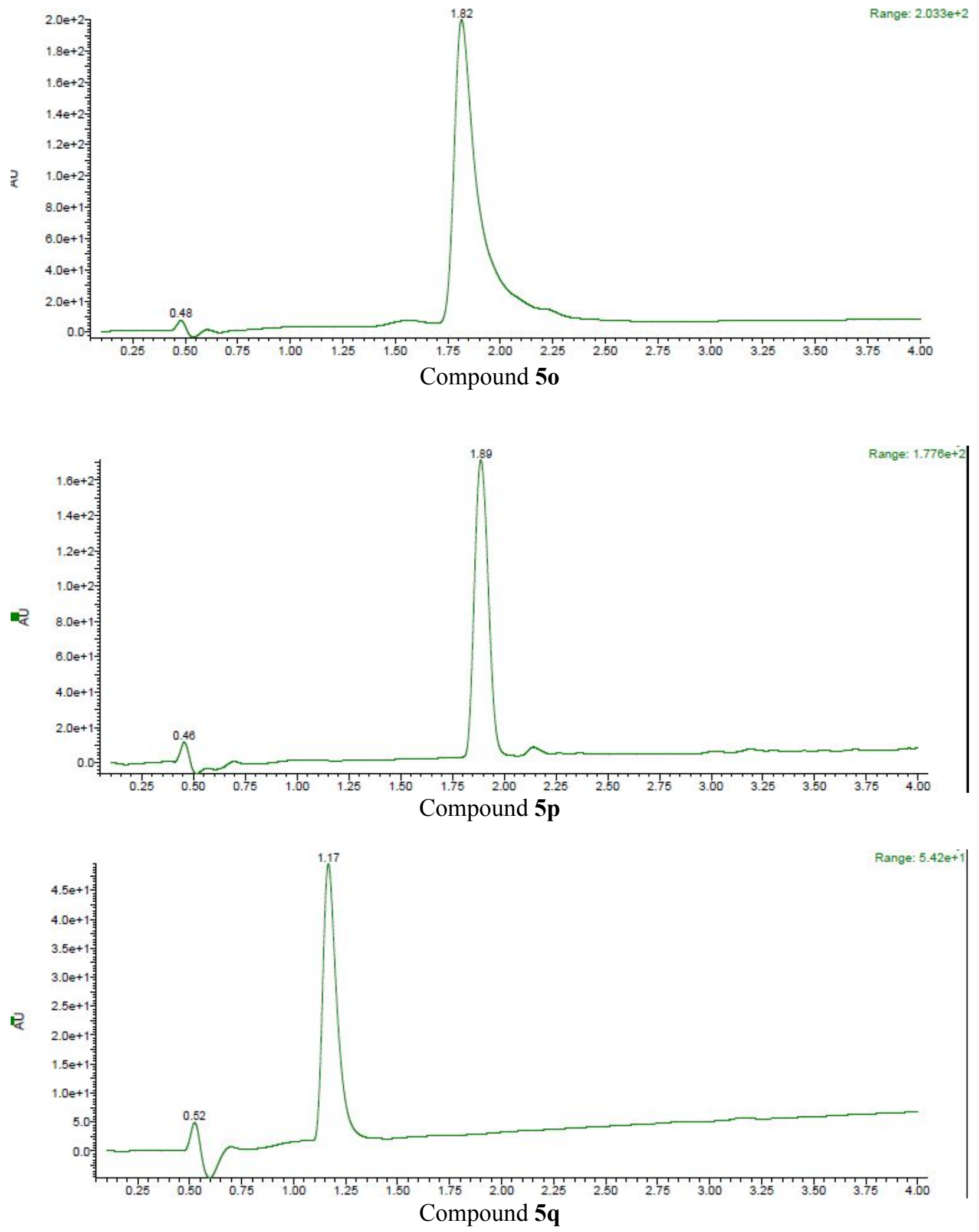

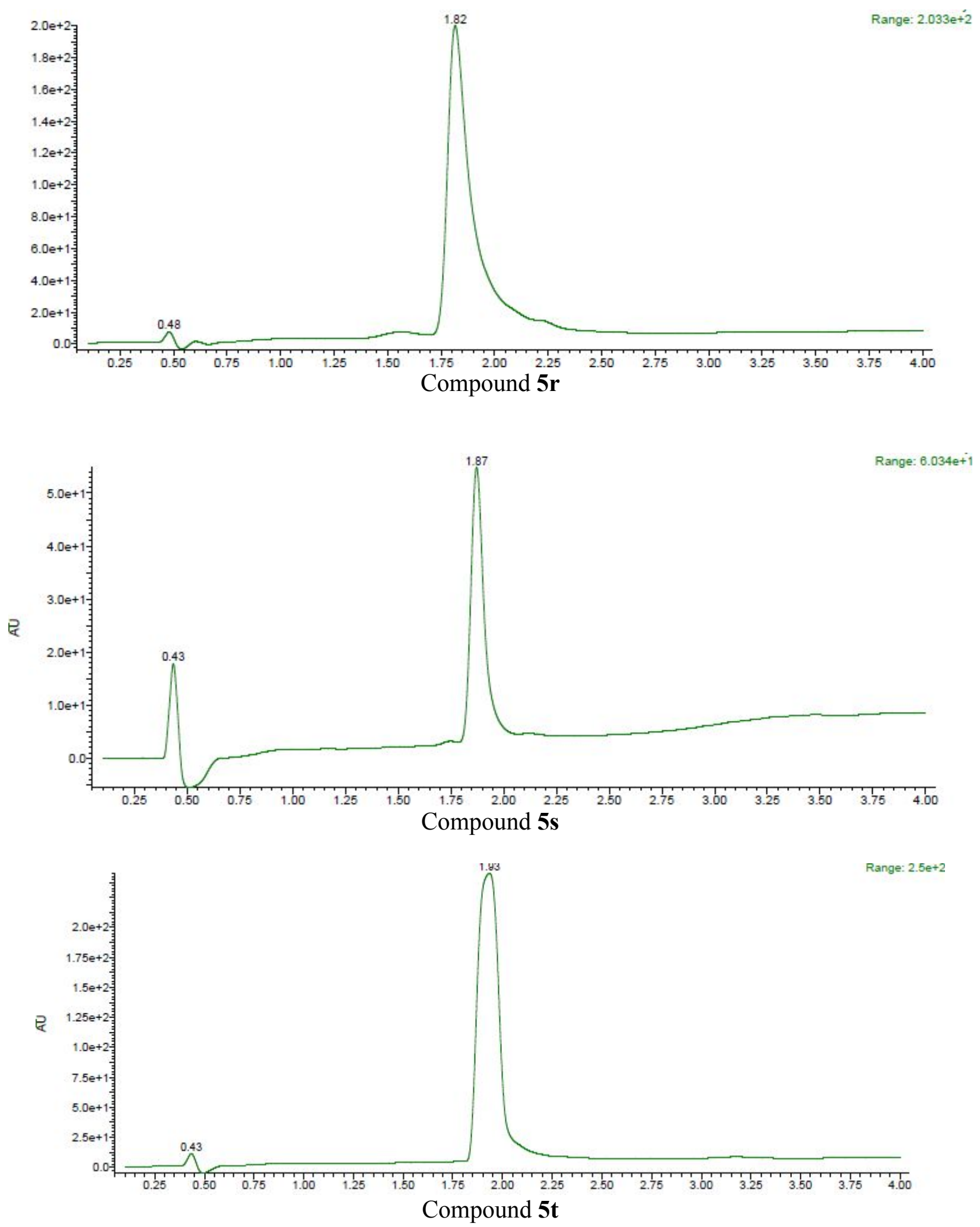

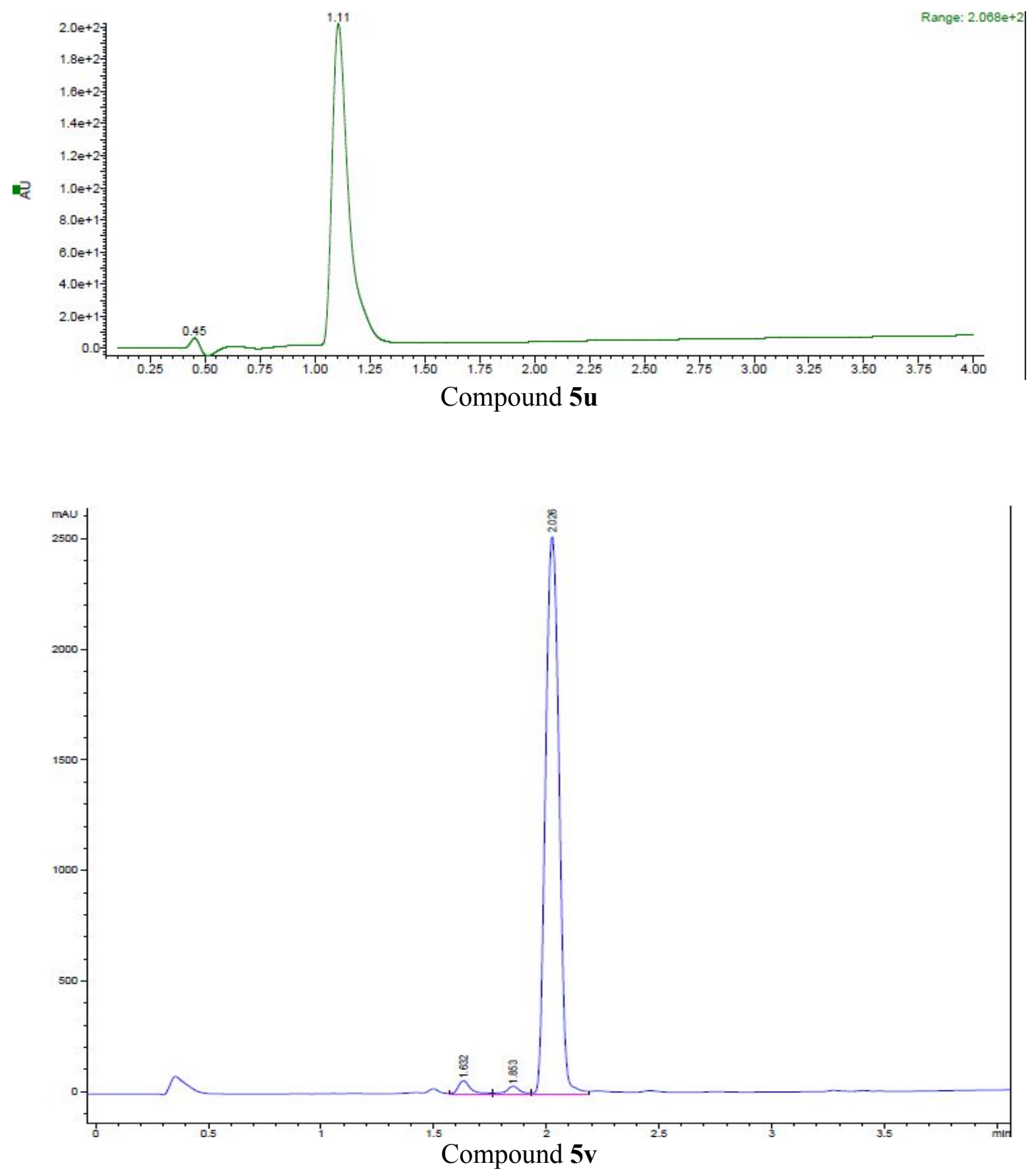

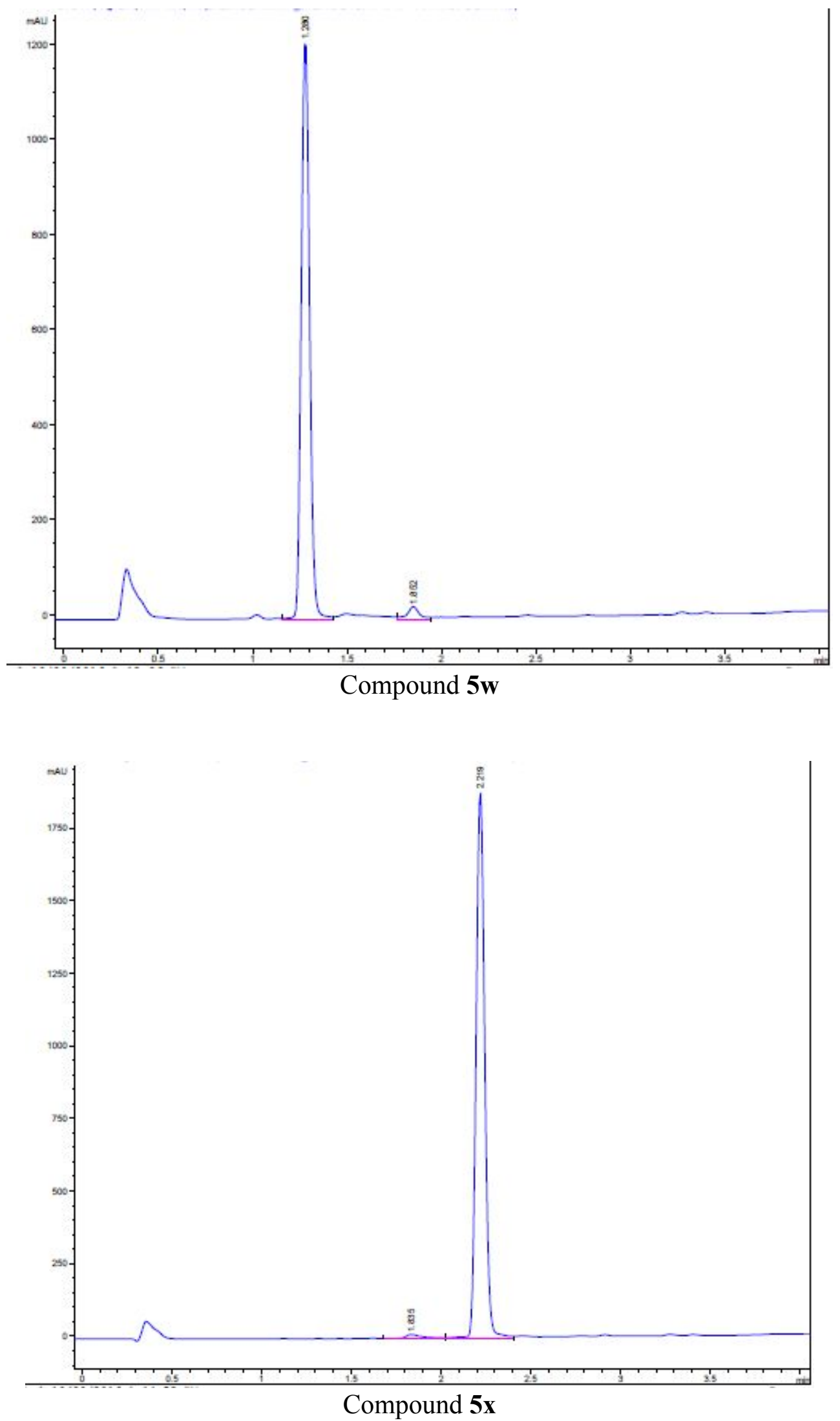




Compound $\mathbf{5 y}$

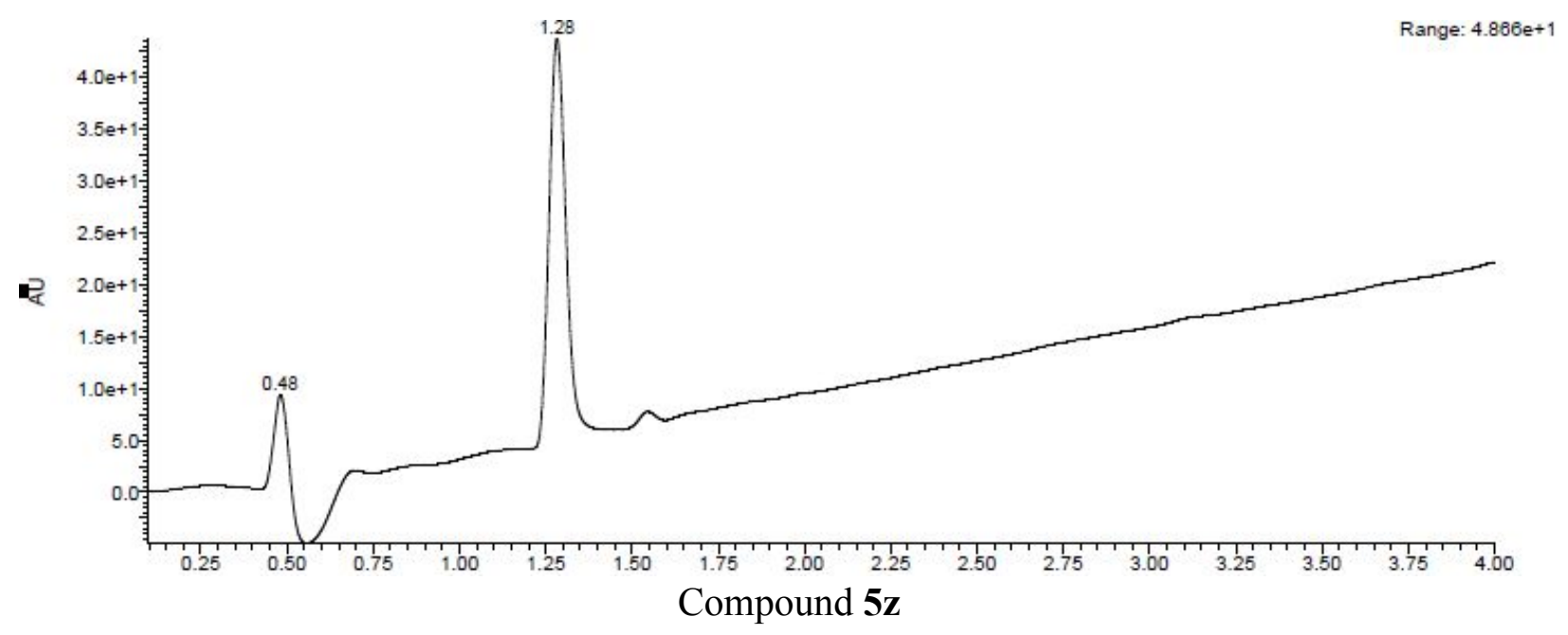



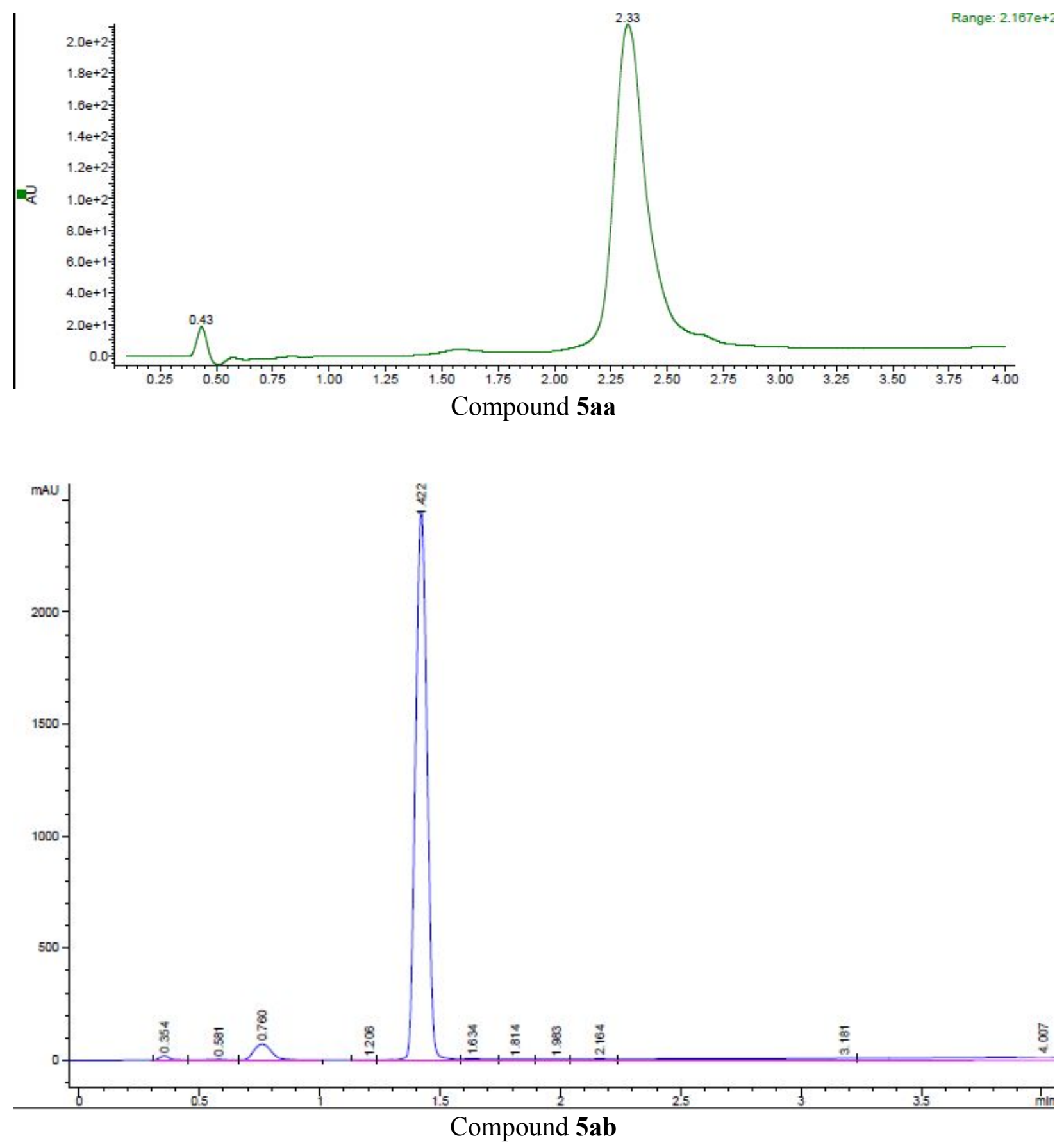

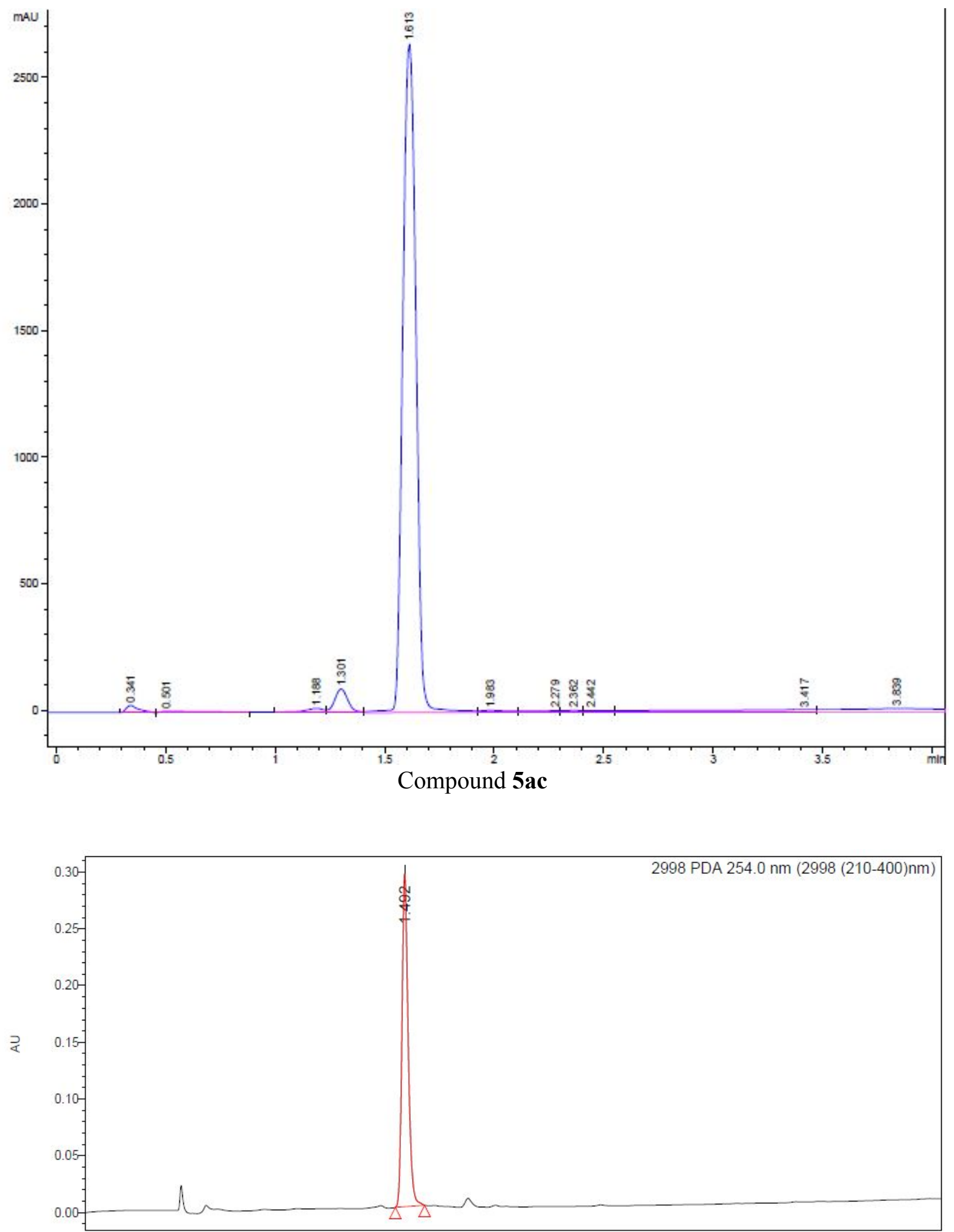

Compound 5ad 



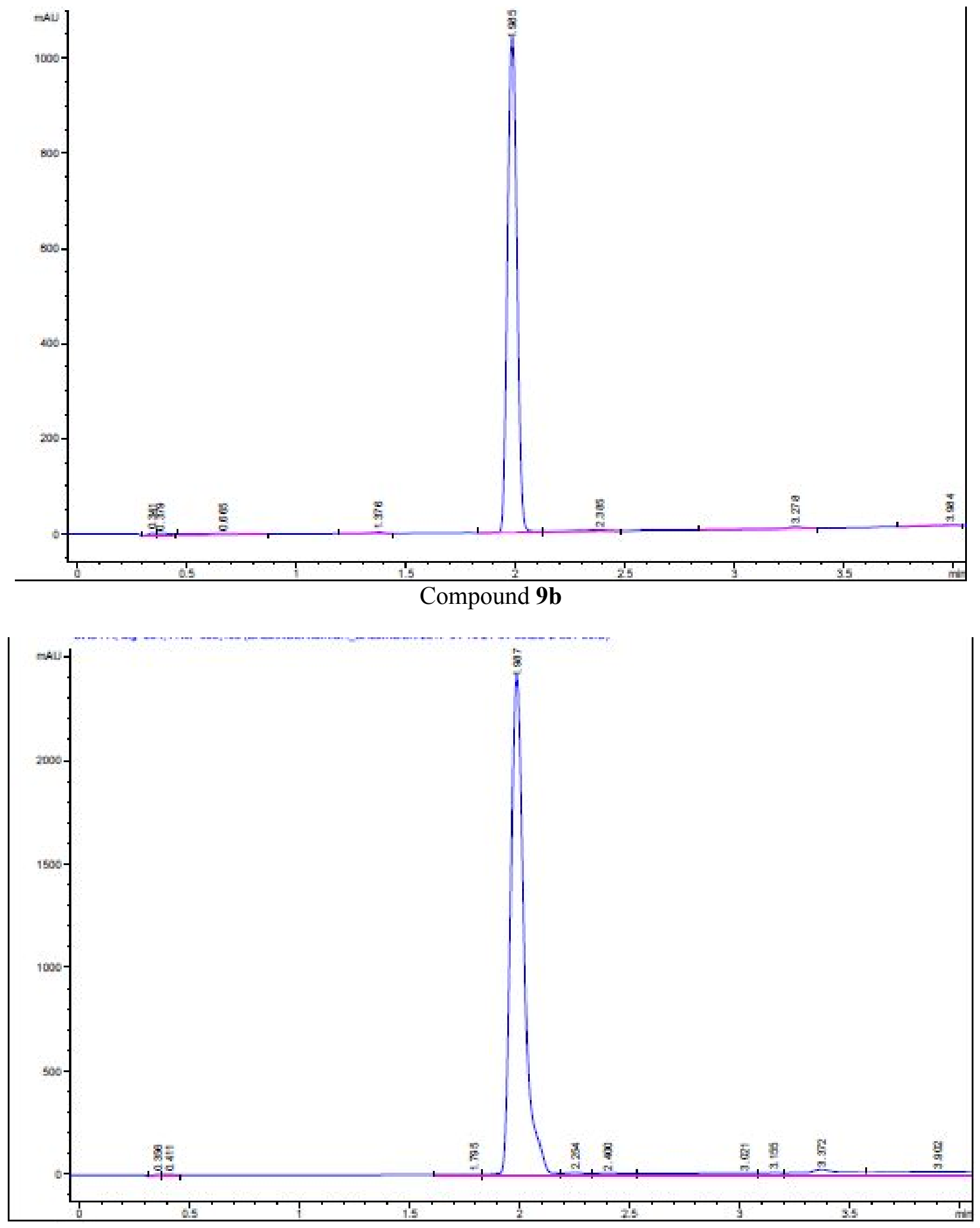

Compound 10 

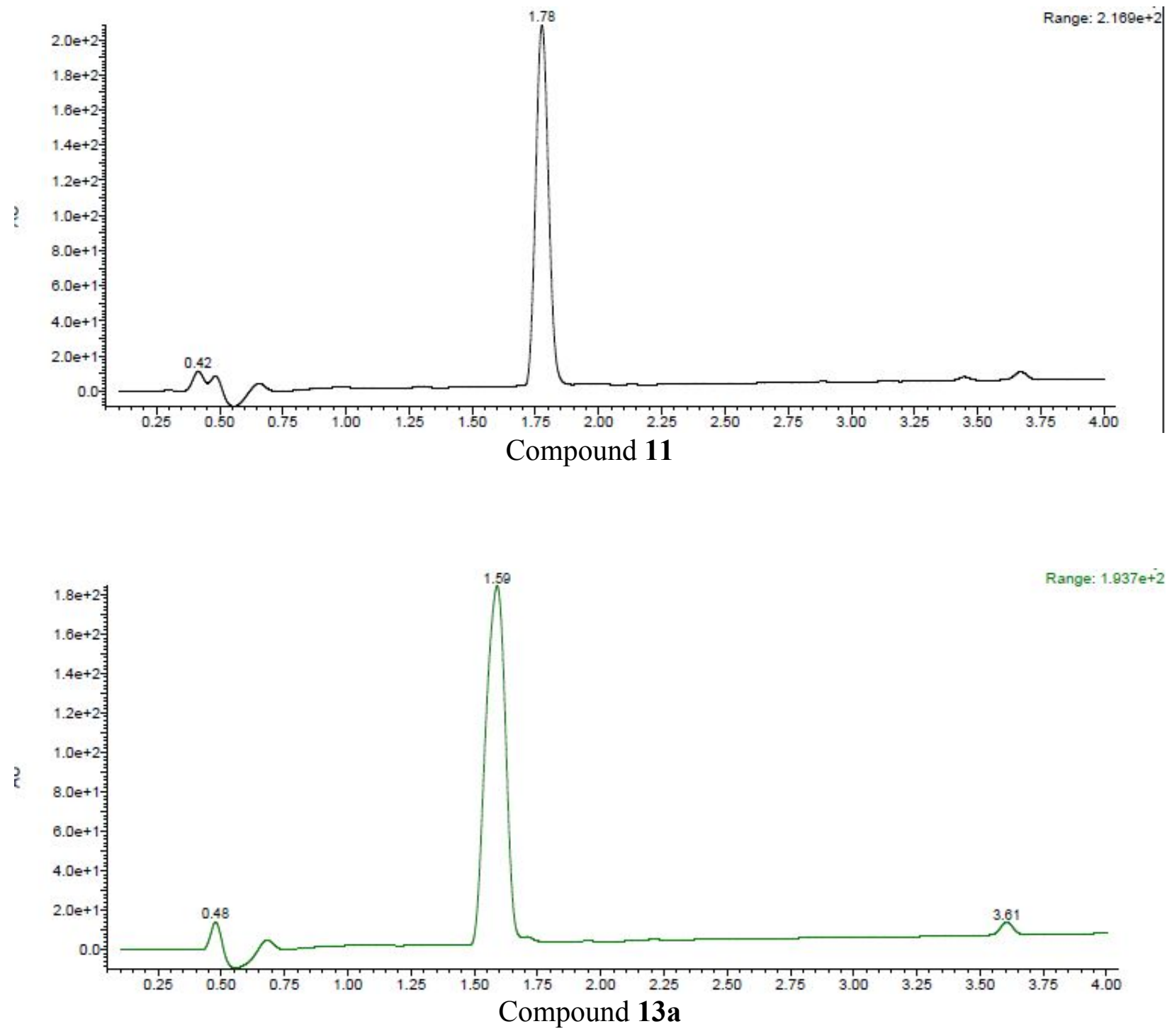


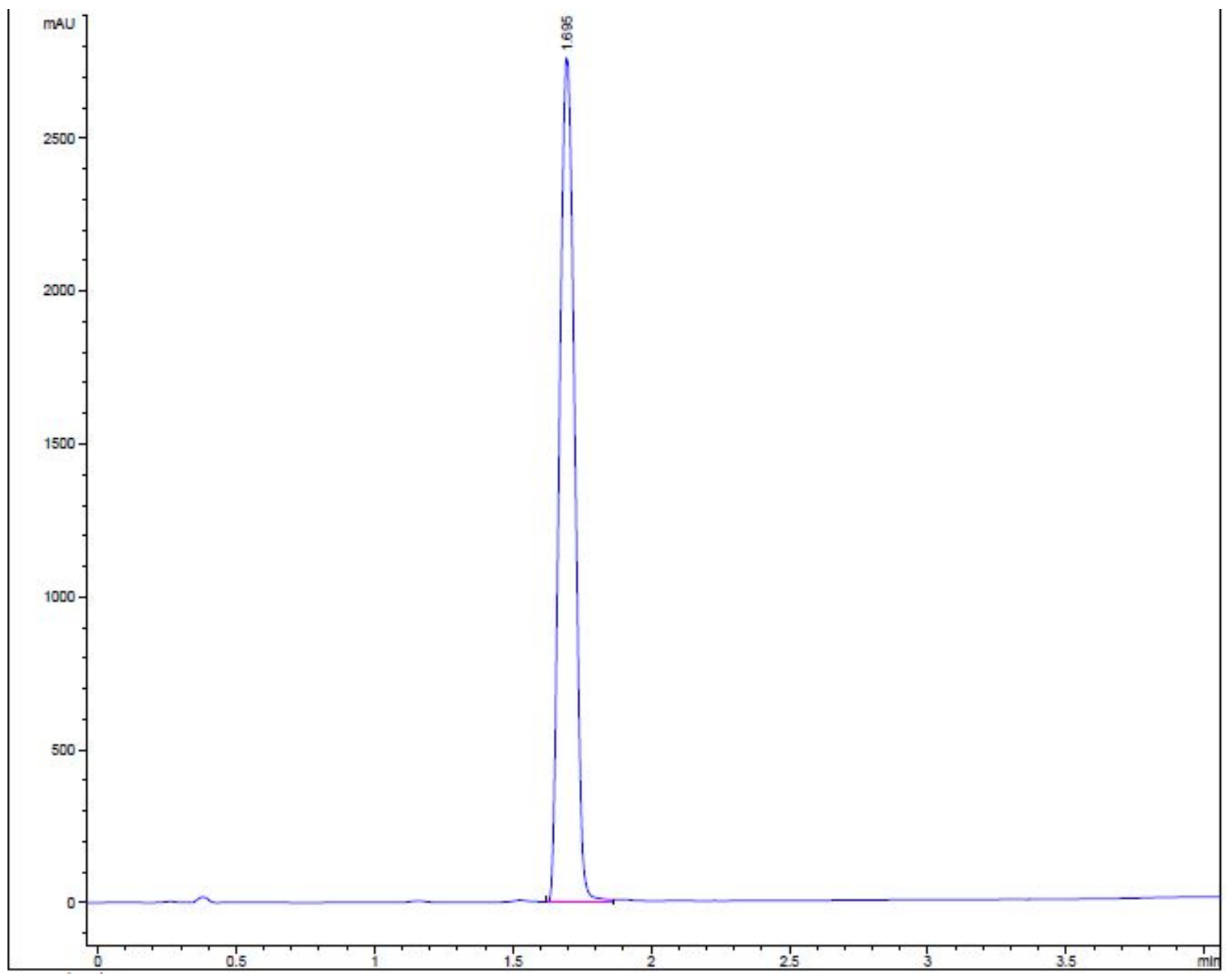

Compound 13b 


\section{REFERENCES}

1. Mercer, L.; Bowling, T.; Perales, J.; Freeman, J.; Nguyen, T.; Bacchi, C.; Yarlett, N.; Don, R.; Jacobs, R.; Nare, B. 2,4-Diaminopyrimidines as potent inhibitors of Trypanosoma brucei and identification of molecular targets by a chemical proteomics approach. PLoS Negl. Trop. Dis. 2011, 5, e956.

2. Muller, I. B.; Domenicali-Pfister, D.; Roditi, I.; Vassella, E. Stage-specific requirement of a mitogen-activated protein kinase by Trypanosoma brucei. Mol. Biol. Cell 2002, 13, 3787-3799. 3. Wei, Y.; Li, Z. Distinct roles of a mitogen-activated protein kinase in cytokinesis between different life cycle forms of Trypanosoma brucei. Eukaryot. Cell 2014, 13, 110-118.

4. Batista, M.; Kugeratski, F. G.; de Paula Lima, C. V.; Probst, C. M.; Kessler, R. L.; de Godoy, L. M.; Krieger, M. A.; Marchini, F. K. The MAP kinase MAPKLK1 is essential to Trypanosoma brucei proliferation and regulates proteins involved in mRNA metabolism. $J$. Proteomics 2017, 154, 118-127.

5. Valenciano, A. L.; Knudsen, G. M.; Mackey, Z. B. Extracellular-signal regulated kinase 8 of Trypanosoma brucei uniquely phosphorylates its proliferating cell nuclear antigen homolog and reveals exploitable properties. Cell Cycle 2016, 15, 2827-2841.

6. Bettayeb, K.; Oumata, N.; Echalier, A.; Ferandin, Y.; Endicott, J. A.; Galons, H.; Meijer, L. CR8, a potent and selective, roscovitine-derived inhibitor of cyclin-dependent kinases. Oncogene 2008, 27, 5797-5807.

7. Bain, J.; Plater, L.; Elliott, M.; Shpiro, N.; Hastie, C. J.; McLauchlan, H.; Klevernic, I.; Arthur, J. S.; Alessi, D. R.; Cohen, P. The selectivity of protein kinase inhibitors: a further update. Biochem. J. 2007, 408, 297-315.

8. Brix, D. M.; Rafn, B.; Bundgaard Clemmensen, K.; Andersen, S. H.; Ambartsumian, N.; Jaattela, M.; Kallunki, T. Screening and identification of small molecule inhibitors of ErbB2induced invasion. Mol. Oncol. 2014, 8, 1703-1718.

9. Konsoula, R.; Jung, M. In vitro plasma stability, permeability and solubility of mercaptoacetamide histone deacetylase inhibitors. Int. J. Pharm. 2008, 361, 19-25.

10. Viswanadhan, V. N.; Ghose, A. K.; Revankar, G. R.; Robins, R. K. Atomic physicochemical parameters for three dimensional structure directed quantitative structure-activity relationships. 4. Additional parameters for hydrophobic and dispersive interactions and their 
application for an automated superposition of certain naturally occurring nucleoside antibiotics. $J$. Chem. Inf. Model 1989, 29, 163-172.

11. Ferrins, L.; Sharma, A.; Thomas, S. M.; Mehta, N.; Erath, J.; Tanghe, S.; Leed, S. E.; Rodriguez, A.; Mensa-Wilmot, K.; Sciotti, R. J.; Gillingwater, K.; Pollastri, M. P. Anilinoquinoline based inhibitors of trypanosomatid proliferation. PLoS Negl. Trop. Dis. 2018, $12, \mathrm{e} 0006834$. 